\title{
Absarokites from the Western Mexican Volcanic Belt: Constraints on Mantle Wedge Conditions
}

\author{
by \\ Marc Hesse \\ HBSc University of Edinburgh 2000
}

Submitted to the Joint Committee for Marine Geology and Geophysics in partial fulfillment of the requirements for the degree Masters of Science in Oceanography in the MIT-WHOI Joint Program

August 2002

(C2002 MIT-WHOI Joint Program

All rights reserved

\section{Signature of}

Author

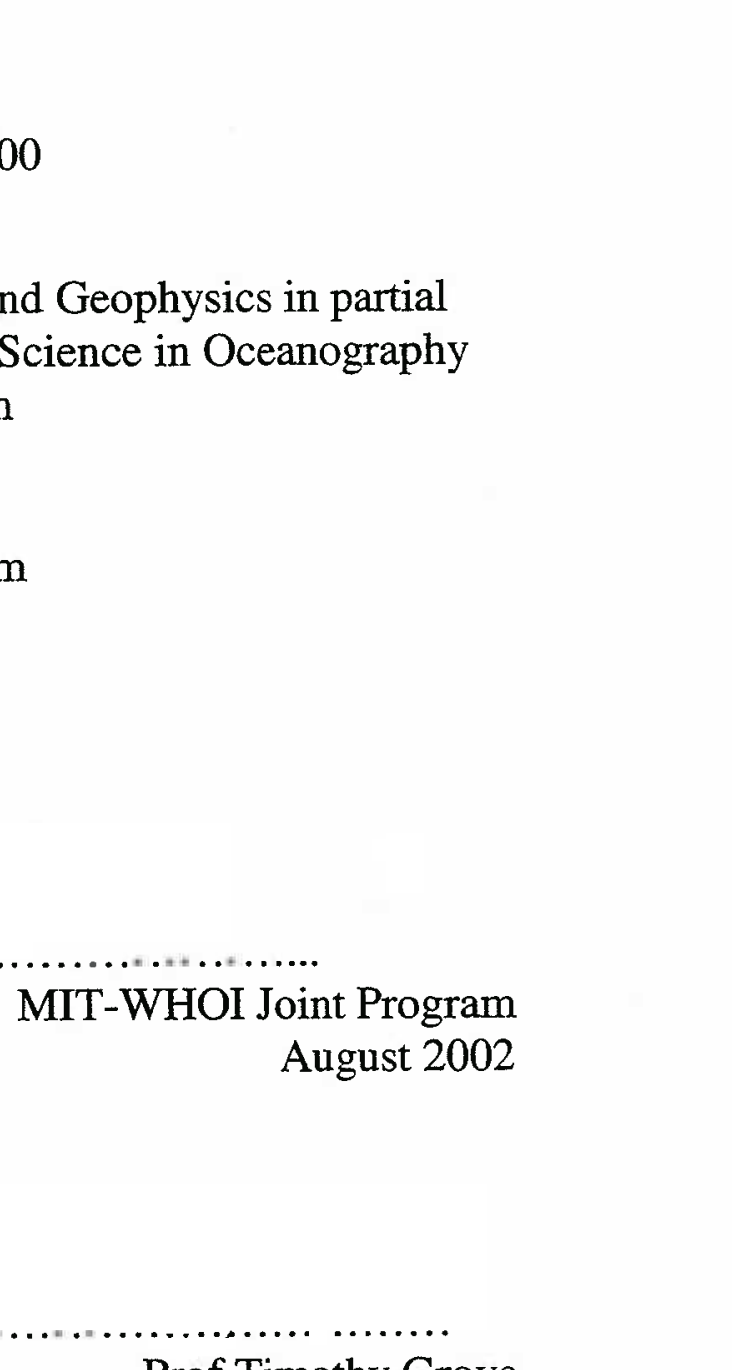

physics in partial
in Oceanography

WHOI Joint Program
August 2002
$\ldots$

Certified

by

Prof Timothy Grove

Thesis Advisor

Accepted

by

Prof Timothy Grove

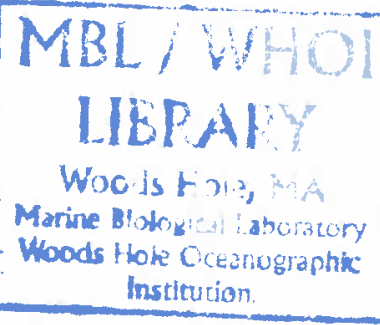

Chair of JCMGG 
Abstract We have investigated the near liquidus phase relations of a primitive absarokite from the Mascota region in Western Mexico. Sample M.102 was chosen because it has high MgO contents, a high $\mathrm{Mg \#}$ and Fo90 olivine phenocrysts, indicating it is primitive mantle melt. High-pressure experiments on a synthetic analogue of the absarokite composition with a $\mathrm{H}_{2} \mathrm{O}$ content of either $\sim 1.7 \mathrm{wt} \%$ or $\sim 5.1 \mathrm{wt} \%$ were carried out in a piston cylinder apparatus. The composition with $\sim 1.7 \mathrm{wt} \% \mathrm{H}_{2} \mathrm{O}$ is multiply saturated with olivine and orthopyroxene as liquidus phases at $1.6 \mathrm{GPa}$ and $1400^{\circ} \mathrm{C}$. At the same pressure clinopyroxene appears $30^{\circ} \mathrm{C}$ below the liquidus. With a $\mathrm{H}_{2} \mathrm{O}$ content of $\sim 5.1 \mathrm{wt} \%$ composition M.102 is multiply saturated with olivine and orthopyroxene on the liquidus at $1.7 \mathrm{GPa}$ and $1300^{\circ} \mathrm{C}$. Assuming batch melting, we suggest that absarokite M.102 segregated from a depleted lherzolite or harzburgite residue at depth $\sim 50 \mathrm{~km}$ depth in the mantle wedge. Unlike most lavas in the region, the absarokite has not ponded and fractionated at the crust mantle interface $(\sim 35-40 \mathrm{~km})$, and the temperatures of multiple saturation indicate that the mantle wedge beneath the Jalisco block is hotter than previously thought. The low degree batch melting of an original metasomatised harzburgite source, can produce the observed trace element abundances. The liquidus phase relations are not consistent with the presence of non-peridotitic veins at the depth of last equilibration. Therefore, we propose that the Mascota absarokites segregated at an apparent melt fraction of less than $5 \%$ from a depleted peridotitic source. They initially formed by a small degree of melting of a metasomatised original source at greater depth.

\section{Introduction}

Two main processes for generating melts in subduction zones are decompression melting due to corner flow and/or extension (Luhr, 1997; Sisson and Bronto, 1998; Elkins Tanton et al., 2001) and melting due to hydrous metasomatism of the mantle wedge above the subducting slab (Gill, 1981). If decompression melting occurs during mantle flow into the mantle wedge, it will leave behind a depleted often harzburgitic mantle that will be metasomatised by a slab component. This metasomatism can either be localized, as mineralogically distinct veins (Vidal et al., 1989; Foley, 1992a;1992b), or distributed in the form of a phlogopite and/or amphibole bearing peridotite. Potassium, sodium and silica are the major elements that are most strongly enriched in the metasomatic agent that has been interpreted either as a $\mathrm{H}_{2} \mathrm{O}$ rich fluid (Stolper and Newman, 1994; Grove et al., 2002) or a slab melt (Rapp et al., 1999; Rose et al., 2001). Calc-alkaline and especially the highly potassic volcanic rocks such as lamprophyres and members of the AbsarokiteShoshonitie-Bankanite series (Iddings, 1895) have been interpreted as partial melts of metasomatised/veined peridotitic mantle (Tatsumi and Koyaguchi, 1989). Luhr (1997) concluded that the highly potassic lavas in Western Mexico represent the "the essence of subduction zone 
magmatism". Absarokites are amongst the most primitive of these potassic volcanic rocks, and understanding their petrogenesis is important to constraining the conditions of melt generation in the metasomatised/veined mantle wedge.

We report the liquidus phase relations of the most primitive potassic lava (M102, Table 1) from the Mascota graben on the Jalisco block in Western Mexico (Carmichael et al., 1996). Sample M102 is an absarokite that is part of a Pleistocene-Holocene volcanic suite ranging from absarokites and minettes to basaltic andesites and spessartites. Carmichael et al. (1996) used a petrographic classification (Iddings, 1895; Nicholls and Carmichael, 1969) to name the rocks from the Mascota graben. Sample M.102 comprises phenocrysts of olivine and augite in a matrix of pyroxene, plagioclase and sanidine and therefore classifies as an absarokite. Due to its unusually low $\mathrm{K}_{2} \mathrm{O} / \mathrm{Na}_{2} \mathrm{O}$-ratio compared to average absarokites (Morrison, 1980) it is also referred to as sodic absarokite (Table 1). In the commonly used chemical classification diagram of high potassic volcanic rocks, $\mathrm{K}_{2} \mathrm{O}$ vs. $\mathrm{SiO}_{2}$ (Peccerillo and Taylor, 1976) sample M.102 is identified as a basalt (Figure 1). In this paper we will refer to it as an absarokite.

In the following paragraphs we briefly summarize the regional geology and plate tectonic setting that are important for petrogenesis of the Mascota potassic lavas. For a more extensive review of the history of the Rivera plate, see DeMets and Traylen (2000) and for tectonics and basaltic volcanism of the Jalisco block, see Luhr (1997).

\section{The Rivera plate}

The arrival of the Pacific-Farallon seafloor spreading center at the convergent margin of North America $\sim 28 \mathrm{Ma}$ ago, broke the Farallon plate up into several smaller plates (Atwater, 1970).

Offshore Western Mexico two such fragments, the Rivera and Cocos plate are currently subducting along the Middle American trench (Figure 2). The Rivera plate that descends underneath the Jalisco block has moved independently for at least $10 \mathrm{Ma}$ (DeMets and Traylen, 2000). The Rivera plate is an oceanic microplate with a complex plate motion history and significant internal deformation. Like other oceanic microplates its present rotation pole is close to the location of the plate and the relative plate motion is governed by shear along the plate boundaries rather than slab pull (DeMets and Traylen, 2000). Figure 2 shows that the Rivera plate moved orthogonal to the trench prior to 7.9 Ma slowing from a convergence rate of $\sim 50 \mathrm{~mm} / \mathrm{yr}$ at $9 \mathrm{Ma}$ to $\sim 1 \mathrm{~mm} / \mathrm{yr}$ at $5 \mathrm{Ma}$. After $3.6 \mathrm{Ma}$ the motion of the Rivera plate became parallel to the trench, implying a cessation of subduction from 2.6 Ma to 1.0 Ma. In the southern part of the Rivera-North American plate boundary the trench normal subduction resumed after $1 \mathrm{Ma}$ (DeMets and Traylen, 2000). At the present time the Rivera 
plate subducts at an angle of $\sim 45^{\circ}$ and the Cocos plate dips $\sim 30^{\circ}$ in the northwest and continually flattens towards the southeast to an angle of $\sim 20^{\circ}$ (Pardo and Suarez, 1993;1995). The age of the Rivera plate currently subducting at the trench is $\sim 10 \mathrm{Ma}$ old (DeMets and Traylen, 2000).

\section{Volcanism in the Jalisco block}

The subduction of the Farallon plate and later its fragments along the Middle American trench formed the Mexican Volcanic Belt (MVB), which has been active at least since the Miocene (Ferrari et al., 1994; Righter, 2000). The lavas studied here occur on the Jalisco block, sometimes also called the Tepic-Colima block, situated between the northwestern-MVB and the Middle American trench. Two continental rift zones, and the Middle American trench bound the Jalisco block (Figure 2). In the northeast a series of grabens called the Tepic-Zacoalco rift zone, coincides with the large andesitic central volcanoes of the northwestern MVB (Allan, 1986; Moore et al., 1994; Righter et al., 1995; Rosas Elguera et al., 1996). Normal faulting with a strike-slip component initiated in the early Pliocene (4.2 Ma) and continues into the Holocene. The northwestern MVB that coincides with the Tepic-Zacoalco rift is dominated by calc-alkaline rocks associated with large andesitic volcanoes (Carmichael et al., 1996), but intra-plate type alkaline rocks are common throughout the Pliocene and Pleistocene (Righter and Carmichael, 1992; Righter et al., 1995; Righter and Rosas-Elguera, 2001). The Tepic-Zacoalco rift has also been interpreted as continental expression of the Tamayo Fracture zone (Righter et al., 1995).

In the east the Jalisco block is bounded by the Colima rift zone, a graben that experienced $1.5-3.3 \mathrm{~km}$ of extension since the early Pliocene (Allan, 1986) and is still active (Suarez et al., 1994). The submarine Manzanillo canyon bounds the Jalisco block to the southwest and is interpreted as the offshore extension of the Colima rift zone (Khutorskoy et al., 1994). Since the late Miocene ( $10 \mathrm{Ma}$ ) calc-alkaline volcanism has been widespread in the Colima rift. Coeval lamprophyric volcanism occurred since the early Pliocene $(\sim 4.5 \mathrm{Ma})$ and both continue into the Holocene. The interior of the Jalisco block has also experienced extension, forming the small, NNW trending Talpa and Mascota grabens, and the larger Atenguillo graben (black star in Figure 2). During the Pleistocene and Holocene potassic and calc-alkaline lavas have erupted, in the grabens and their surroundings (Carmichael et al., 1996). The Mascota volcanic suite ranges from primitive absarokites and minettes to andesites and their lamprophyric equivalent spessartite. Although the observed trends cannot be produced by fractionation and assimilation, Carmichael et al. (1996) assume that they are genetically related due to their close proximity in space and time. 


\section{Starting compositions}

Sample M.102 was chosen as an experimental starting composition. M.102 shows all signs of a melt close to equilibrium with mantle peridotite including a high $\mathrm{MgO}$ content, together with a high $\mathrm{Mg \#}$ (= molar $\mathrm{MgO} /[\mathrm{MgO}+\mathrm{FeO}]$ ) and high concentrations of $\mathrm{Cr}$ and $\mathrm{Ni}$ (Table 1). Another important indicator of a mantle derived melt is the presence of $\mathrm{Fog}_{00}$-olivine phenocrysts (Fo $=$ molar $\mathrm{MgO} /[\mathrm{MgO}+\mathrm{FeO}])$, and a Fe-Mg partition coefficient $\mathrm{K}_{\mathrm{D}}{ }^{\mathrm{Fe}-\mathrm{Mg}}=0.29\left(\mathrm{~K}_{\mathrm{D}}^{\mathrm{Fe}-\mathrm{Mg}}=\right.$ molar $\left[\mathrm{MgO}^{\text {melt }} * \mathrm{FeO}^{\text {olivine }}\right] /\left[\mathrm{MgO}^{\text {olivine }} * \mathrm{FeO}^{\text {melt }}\right]$ ) between olivine and melt, indicating that the melt was in equilibrium with $\mathrm{Fo}_{90}$ mantle olivine. We therefore assume the absarokite M.102 is a primary melt from a peridotite mantle that has not been modified significantly by post segregation processes. In the Mascota series the samples with the highest potassium contents have the highest Mg\#'s, arguing against contamination by continental crust (Carmichael et al., 1996). The absence of a coexisting olivine and orthopyroxene on the liquidus of several experimental studies of potassic and ultrapotassic lavas has led to the conclusion that some might not have a peridotite source and therefore the usual selection criteria for primitive melts do not apply (Foley, 1992a). However, M.102 is only mildly potassic (Figure 1) and is closely related in space and time to basaltic andesites in the Mascota series that are assumed to be derivatives of hydrous peridotite melting (Carmichael et al., 1996). Our experimental results confirm this assumption.

A dry and a hydrous synthetic analogue of the composition of sample M.102 (Table 1) were prepared by mixing high purity oxides, hydroxides, and silicates (Gaetani and Grove 1998). $\mathrm{H}_{2} \mathrm{O}$ was added to the hydrous mix as brucite $\mathrm{Mg}(\mathrm{OH})_{2}$, which breaks down to $\mathrm{MgO}$ and $\mathrm{H}_{2} \mathrm{O}$ at run temperatures. Adding water as brucite ensures that all hydrous experiments have same initial $\mathrm{H}_{2} \mathrm{O}$ concentration. The amount of $\mathrm{H}_{2} \mathrm{O}$ in the composition can be adjusted by choosing the fraction of $\mathrm{MgO}$ replaced by $\mathrm{Mg}(\mathrm{OH})_{2}$. In our hydrous mix we have replaced all $\mathrm{MgO}$ by $\mathrm{Mg}(\mathrm{OH})_{2}$ and therefore added the maximum amount of $5.1 \mathrm{wt} \% \mathrm{H}_{2} \mathrm{O}$. These synthetic mixes were subsequently ground in an agate mortar under ethanol for 6 hrs. The mixes were stored in a dessicator at room temperature. Electron microprobe analyses of superliquidus glasses of both mixes showed large alkali losses during mix preparation and made it necessary to correct the sodium and potassium concentrations in both compositions. Sodium and potassium were added as $1.0 \mathrm{~N}$ solutions of $\mathrm{NaOH}$ and $\mathrm{KOH}$ in methanol, which are strongly hygrophylic and resulted in $\sim 1.7 \%$ wt $\mathrm{H}_{2} \mathrm{O}$ in the initially dry mix (Table 1). The water contents of the mixes estimated from summation deficit in Table 1, are 1.5 and $4.1 \mathrm{wt} \% \mathrm{H}_{2} \mathrm{O}$ for the less hydrous and the hydrous mix. For selected runs the $\mathrm{H}_{2} \mathrm{O}$ content was directly calculated by oxygen balance. Oxygen abundance in the glass was analyzed by electron microscopy and all oxygen left over after forming oxides is assumed to be bound in $\mathrm{H}_{2} \mathrm{O} . \mathrm{H}_{2} \mathrm{O}$ 
estimates from oxygen balance are generally higher than the summation deficits (Table $4 \& 5$ ). For some experiments the $\mathrm{H}_{2} \mathrm{O}$ estimates from oxygen balance lead to totals higher than $101.5 \mathrm{wt} \%$. Since the oxygen measurement is sensitive to the thickness of the carbon coat on the samples, the high estimates of $\mathrm{H}_{2} \mathrm{O}$ may be related to the variations in carbon coat thickness. We therefore prefer the $\mathrm{H}_{2} \mathrm{O}$ estimates that lead to reasonable total from $98.5 \mathrm{wt} \%$ to $101.5 \mathrm{wt} \%$. The assumed $\mathrm{H}_{2} \mathrm{O}$ content of the less hydrous runs is therefore $1.7 \mathrm{wt} \%$ as calculated from oxygen balance of experiment $\mathrm{D} 127$. For the hydrous mix the summation deficit $\left(4.1 \mathrm{wt} \% \mathrm{H}_{2} \mathrm{O}\right)$ and oxygen balance techniques ( $5.9 \mathrm{wt} \% \mathrm{H}_{2} \mathrm{O}$ ) show a discrepancy. As compromise between the two estimates we assume that the $\mathrm{H}_{2} \mathrm{O}$ content of the mix is the nominal $5.1 \mathrm{wt} \% \mathrm{H}_{2} \mathrm{O}$ that have been added initially. Due to problems with $\mathrm{MgO}$ contamination from the experimental assembly and Fe loss during the experiments, the actual experimental bulk compositions differ from the composition of sample M.102. Best estimates for the less hydrous $\left(1.7 \mathrm{wt} \% \mathrm{H}_{2} \mathrm{O}\right)$ and hydrous $\left(5.1 \mathrm{wt} \% \mathrm{H}_{2} \mathrm{O}\right)$ compositions are given in Table 1 and will be called MEX-1.7 \& MEX-5.1 below. The estimates are the means of repeated electron microprobe analyses of runs that did not contain any visual solid phases. For Mix1.7 the 56 analyses from experiments D87, D90 and D127 (Table $2 \& 4$ ) were included in the mean. For all major and minor oxides, except $\mathrm{FeO}^{*}$ in mix MEX-5.1 138 analyses from experiments $\mathrm{B} 848$, B854, B855 and B856 were included in reported mean. Experiment B848 has lost Fe during the run and was not included in the mean $\mathrm{FeO}^{*}$ reported in Table 1.

\section{Experimental methods}

Two different capsule materials were used. Prefabricated carbon capsules were used for the less hydrous experiments (mix MEX-1.7) with higher liquidus temperatures (dry assemblage). The capsule material for the lower temperature, hydrous experiments (mix MEX-5.1), was $\mathrm{Au}_{80} \mathrm{Pd}_{20}$ presaturated with Fe to minimize Fe loss to the capsule material during the experiment (Gaetani and Grove, 1998). The $\mathrm{Au}_{80} \mathrm{Pd}_{20}$ capsules were pre-saturated by filling them with MEX-1.7 mix, before running them for 5 days in an 1 atm Deltech furnace at $1250^{\circ} \mathrm{C}$ and at an oxygen fugacity at the QFM buffer. After the conditioning the glass was removed from the capsule by dissolving it in hot $\mathrm{HF}$ with a drop of $\mathrm{HNO}_{3}$. The cleaned, pre-saturated capsules were filled with MEX-5.1 starting material and welded shut. The pre-saturated $\mathrm{Au}_{80} \mathrm{Pd}_{20}$ inner capsule is placed into a handmade graphite outer capsule (hydrous assemblage). The hydrous and dry experimental assemblages are shown in Figure 3. In the dry assemblage a large graphite filled cavity below the graphite capsule was necessary to avoid contamination of the sample by the $\mathrm{MgO}$ spacers. First experiments showed that that melts produced by the starting composition are unusually mobile in graphite, and the stress 
field in the assemblage caused melt channels to migrate downward (Figure 4). Placing the dry capsule onto a cavity filled with powdered graphite reduced the $\mathrm{MgO}$ contamination significantly. All experiments were conducted in a $1 / 2$ " solid medium piston cylinder device (Boyd and England, 1960). The piston-in technique was used (Johannes et al., 1971), the experiments were pressurized to $1 \mathrm{GPa}$ at room temperature and heated to $865^{\circ} \mathrm{C}$ at a rate of $100^{\circ} \mathrm{C} / \mathrm{min}$, where the sample was held for 6 minutes. The pressure was then raised to run pressure and the temperature was raised at a rate of $50^{\circ} \mathrm{C} / \mathrm{min}$ to the final run temperature. Experiments were quenched by turning off the power supply to the temperature controller. Cooling rates were fast enough to avoid growth of quench crystals in most dry runs. Hydrous runs produced excessive quench growth at $\sim 30^{\circ} \mathrm{C}$ below the liquidus, pressure quenching did not improve the results.

The run temperature was measured using $\mathrm{W}_{97} \mathrm{Re}_{3}-\mathrm{W}_{75} \mathrm{Re}_{25}$ thermocouple with no correction for the effect of pressure on the thermocouple EMF. The temperature at the center of the sample is $20^{\circ} \mathrm{C}$ hotter than at the location of the thermocouple bead and all reported temperatures have been corrected for this effect. A Eurotherm 818 controller maintained the temperature at $\pm 2{ }^{\circ} \mathrm{C}$ of the target value and the run temperature is believed to be reproducible to $\pm 7^{\circ} \mathrm{C} . \mathrm{BaCO}_{3}$ has been used as pressure medium, and pressure calibration against the Ca-Tschermak breakdown reaction (Hays, 1966) showed that no friction correction is necessary. Experimental durations were kept short to minimize $\mathrm{MgO}$ contamination and in the experiments using graphite capsules and $\mathrm{H}_{2} \mathrm{O}$ loss in the experiments using $\mathrm{Au}_{80} \mathrm{Pd}_{20}$ alloy capsules (Table 2 \& 3).

\section{Analytical methods}

For most experiments, the sample capsule was recovered from the pressure cell, cut in half and mounted in epoxy. At each pressure an entire experimental assemblage was sliced and mounted, to check the uniformity of the distance between the thermocouple and the sample. All experiments were polished to $0.06 \mu \mathrm{m}$ finish, and examined in reflected light and using backscattered electron imaging. Experimental products were analyzed with the MIT JEOL JXA-733 Superprobes using wavelength dispersive spectroscopy (WDS), with a $15 \mathrm{kV}$ accelerating potential and a $10 \mathrm{nA}$ beam. The CITZAF correction package of Armstrong (1995) was used to reduce the data. The atomic number correction of Duncumb and Reed, Heinrich's tabulation of absorption coefficients, and the fluorescence correction of Reed were used to obtain a quantitative analysis (Armstrong, 1995). For the glass phase the beam size was $\sim 10 \mu \mathrm{m}$ and $\mathrm{Na}$ was counted at the beginning of the analysis for 5 s. Other elements were measured for up to $40 \mathrm{~s}$, depending on abundance level. Analytical precision can be inferred from replicate analyses of an andesite glass working standard (38b-129) from a 0.1 MPa experiment (Grove and Juster, 1989). One standard deviation of replicate glass analyses 
expressed as relative percent of oxides are $\mathrm{SiO}_{2}: 0.4 \%, \mathrm{Al}_{2} \mathrm{O}_{3}: 0.9 \%, \mathrm{CaO}: 1.5 \%, \mathrm{MgO}: 1.5 \%$, FeO:1.4\%, $\mathrm{MnO}: 8.1 \%, \mathrm{P}_{2} \mathrm{O}_{5}: 5 \%, \mathrm{Na}_{2} \mathrm{O}: 1.9 \%, \mathrm{~K}_{2} \mathrm{O}: 1.1 \%$, based on 289 individual measurements over 28 analytical sessions. The mean sum of analyses of the anhydrous glass is $99.4 \%$. The $\mathrm{H}_{2} \mathrm{O}$ content in the glasses was estimated by summation deficit, and therefore a maximum estimate. The phase proportions in the run products were estimated by least-squares mass balance. All oxides given in Table 1 were included in mass balance, and sums of the squared residuals are generally smaller than 1.0.

\section{Approach to Equilibrium}

We have not demonstrated an approach to equilibrium in our experiments, as it would require reversal experiments for all possible compositional changes in all phases. At constant temperature and pressure, equilibrium requires that experiments have constant bulk composition for the experimental duration, and that all phases have homogeneous compositions. Achieving homogeneous compositions in the mineral phases, requires experimental run times of 2-3 days, if pyroxenes are present (Baker and Stolper, 1994). In our experiments the strong loss $\mathrm{H}_{2} \mathrm{O}$ and $\mathrm{Fe}$ during the experiments required us to keep the run times as short as possible, to have an approximately constant bulk composition.

Despite the short run times, there are many observations indicating that the experimental phases are sufficiently close to equilibrium. Most experiments are close to the liquidus and experimental products contain more than $80 \%$ glass (Table $2 \& 3$, Figure $9 \mathrm{a} \& 9 \mathrm{~b}$ ). The experimental glass is homogenous judging from the standard deviations given in Table $4 \& 5$. It has been shown that direct synthesis is sufficient to recover equilibrium phase appearance temperatures in experiments with $>40 \%$ glass/melt (Grove and Bence, 1977). Olivine, orthopyroxene and clinopyroxene generally show minor element compositions and solid-liquid partitioning comparable to longer duration experiments. Figure 5 shows that the $\mathrm{Ca}$ and $\mathrm{Al}$ composition of clinopyroxenes in our experiments is comparable to those from longer duration multiple saturation experiments using basaltic compositions (Kinzler and Grove, 1992a; Gaetani and Grove, 1998). The Fe-Mg distribution coefficients $\left(\mathrm{K}_{\mathrm{D}}{ }^{\mathrm{Fe}-\mathrm{Mg}}=\operatorname{molar}\left[\mathrm{MgO}^{\text {melt }} * \mathrm{FeO}^{\text {olivine }}\right] /\left[\mathrm{MgO}^{\text {olivine }} * \mathrm{FeO}^{\text {melt }}\right]\right)$ are close to constant in experiments with the same bulk composition. The mean $\mathrm{K}_{\mathrm{D}}$ 's for all experiments with composition MEX-1.7 (Table 1) and the mean $\mathrm{K}_{\mathrm{D}}$ 's for all experiments with composition MEX-5.1 (Table 1) are within one standard deviation of each other. The mean $\mathrm{Fe}-\mathrm{Mg}$ partition coefficient $\left\langle\mathrm{K}_{\mathrm{D}}{ }^{\mathrm{Fe}-\mathrm{Mg}}\right\rangle_{\mathrm{ol}}$ between olivine and melt is $0.33 \pm 0.01(1 \sigma)$ in experiments with composition MEX-1.7, and $0.32 \pm 0.02$ in experiments with bulk composition MEX-5.1. Values of $\left\langle\mathrm{K}_{\mathrm{D}}{ }^{\mathrm{Fe}-\mathrm{Mg}}\right\rangle_{\mathrm{ol}}$ from longer duration experiments range from 0.34 to 0.30 (Kinzler and Grove, 1992a; Gaetani and Grove, 1998). 
The $\left\langle\mathrm{K}_{\mathrm{D}}{ }^{\mathrm{Fe}-\mathrm{Mg}}\right\rangle_{\mathrm{opx}}$ between orthopyroxene and melt is $0.32 \pm 0.01$ or \pm 0.02 in experiments with bulk composition MEX-1.7 and MEX-5.1 respectively. Longer duration experiments report $\left\langle\mathrm{K}_{\mathrm{D}}^{\mathrm{Fe}-\mathrm{Mg}}\right\rangle_{\mathrm{opx}}$ from 0.27 to 0.33 (Kinzler and Grove, 1992a; Kinzler, 1997). The $\left\langle\mathrm{K}_{\mathrm{D}}{ }^{\mathrm{Fe}-\mathrm{Mg}}\right\rangle_{\mathrm{cpx}}$ for clinopyroxene from experiments with bulk composition MEX-1.7 is $0.38 \pm 0.02$. From experiments with composition MEX-5.1 only experiment $\mathrm{B} 833$ contained clinopyroxene, its $\mathrm{K}_{\mathrm{D}}{ }_{\mathrm{Fe}-\mathrm{Mg}}^{\mathrm{cpx}}$ is 0.34 . Compared to experimental studies using longer experimental duration the $\left\langle\mathrm{K}_{\mathrm{D}}{ }^{\mathrm{Fe}-\mathrm{Mg}}\right\rangle_{\mathrm{cpx}}$ from the less hydrous compositions is higher than the mean value of 0.36 reported by Kinzler (1997). This might reflect the influence of the elevated alkali contents on the Fe-Mg partitioning. The high temperatures, the large amounts of melt present, the consistent partitioning and minor element composition of solid phases observed in our experiments indicate that the experimental phases are close enough to equilibrium to aid in the understanding of the petrogenesis of absarokite M.102.

\section{Experimental Results}

High-pressure experiments on the less hydrous composition (MEX-1.7, Table 1) were conducted from $1.2 \mathrm{GPa}$ to $2.0 \mathrm{GPa}$ and temperatures from $1340^{\circ} \mathrm{C}$ to $1440^{\circ} \mathrm{C}$ (Figure 6a). Experiments on the hydrous composition (MEX-5.1, Table 1) were conducted from $1.2 \mathrm{GPa}$ to $2.0 \mathrm{GPa}$ and temperatures from $1220^{\circ} \mathrm{C}$ to $1340^{\circ} \mathrm{C}$ (Figure $6 \mathrm{~b}$ ). The experimental conditions of all runs are given in Table $2 \& 3$ and the compositions of the experimental products are given in Table $4 \& 5$. In the hydrous runs quench growth was problematic for all runs more than $\sim 30^{\circ} \mathrm{C}$ below the liquidus. The less hydrous composition, with $\sim 1.7 \mathrm{wt} \% \mathrm{H}_{2} \mathrm{O}$, is multiply saturated with olivine and orthopyroxene on the liquidus at $1.6 \mathrm{GPa}$ and $1400^{\circ} \mathrm{C}$ (Figure 6a). At pressures below the multiple saturation point olivine is the liquidus phase, and at pressures above orthopyroxene is stable. The hydrous composition with $\sim 5.1 \mathrm{wt} \% \mathrm{H}_{2} \mathrm{O}$, is multiply saturated with olivine and orthopyroxene at $1.7 \mathrm{GPa}$ and $1290^{\circ} \mathrm{C}$ (Figure 6b). Like the less hydrous composition olivine is the stable liquidus phase at lower pressures and orthopyroxene at higher pressures. Figure 7 shows the dry liquid line of decent at the multiple saturation pressure of $1.6 \mathrm{GPa}$. The experimental composition MEX-1.7 (Table 1) is on the olivine-orthopyroxene reaction boundary in the olivine-diopside-quartz projection. In the olivine-diopside-plagioclase projection (Figure 7) experimental liquids within $70^{\circ} \mathrm{C}$ of the liquidus are close to constant in composition. Together with the appearance of clinopyroxene no more than $30^{\circ} \mathrm{C}$ below the liquidus, this suggests that the starting composition is very close to the multiple saturation point with olivine, orthopyroxene and clinopyroxene. The addition of $\sim 2.6 \mathrm{wt} \% \mathrm{H}_{2} \mathrm{O}$ 
shifts the multiple saturation to higher pressures and lower temperature, but the phase assemblage remains the same.

Figure 8 shows the effect of severe Fe-loss on the phase relations and the pressure of multiple saturation. The black boxes represent experiments using composition MEX-5.1 that have lost 15$25 \% \mathrm{Fe}$ to the capsule during the experiment. Experiments with less than $10 \% \mathrm{Fe}$ loss are shown in gray and reported in Table $3 \& 5$, they are also shown in Figure 6b. Fe loss has decreased the liquidus temperature at $2.0 \mathrm{GPa}$ and the pressure of multiple saturation is decreased from $1.7 \mathrm{GPa}$ to $\sim 1.4 \mathrm{GPa}$. Large iron losses can therefore affect the pressure and temperature of the multiple saturation point and should be minimized in liquidus experiments on natural compositions. Tatsumi and Koyaguchi (1989) used graphite capsules for their dry experiments and untreated platinum capsules for their wet experiments, and observed a similar shift of the multiple saturation point to lower pressures $(-0.5 \mathrm{GPa})$, that is probably caused by Fe-loss to the platinum capsule.

\section{Interpretation of Results}

The high-pressure experiments reported here simulate an isobaric, isothermal batch melting process. Therefore interpretation of the results is clearest, if the process producing the potassic rocks in Mascota region is close to batch melting. Although we know that mantle melting process beneath mid ocean spreading centers is polybaric near fractional decompression melting (Johnson et al., 1990), there are several reasons to believe that conditions recorded by the Mascota absarokites are very close to batch melting. Geodynamic models suggest simple corner flow of the mantle between the subducting and overriding plate. The effects of temperature and stress on mantle viscosities lead to mild depressurization as new asthenosphere is drawn into the mantle wedge. This upwelling is thought to be the mechanism to generate the high aluminum olivine tholeiites (HAOT) found in many arcs (Sisson and Bronto, 1998). The Mascota lavas are erupted in graben structures in the fore-arc (Carmichael et al., 1996), between the main volcanic arc and the oceanic trench (Figure 2). In the fore arc the mantle is thought to flow horizontally or downward, and decompression melting is not possible. Gravity modeling suggest that the crust of the Jalisco block has a thickness near $40 \mathrm{~km}$ and extension has not lead to demonstrable crustal thinning (Molina-Garza and Urrutia-Fucugauchi, 1993; Urrutia-Fugugauchi and Florez-Ruiz, 1996). Therefore contemporary extension does not provide a source for upwelling in the fore arc mantle. The polybaric near fractional melting process beneath mid-ocean ridge spreading centers is caused by an efficient extraction of small melt fractions during mantle upwelling. The absence of mantle upwelling and decompression in the frontal part of the wedge is therefore an argument against polybaric near fractional decompression melting process. Also experimentally studied calc-alkaline lavas show equilibration with mantle peridotite at 
relatively shallow depths just below the crust-mantle transition (Baker et al., 1994). Together with geochemical observations showing fractionation at similar pressures (Lange and Carmichael, 1991), this indicates that melts rising from the mantle wedge commonly pond and reequilibrate at the base of the crust, thereby acquiring the characteristics of batch melts. The inverted thermal gradient in subduction zones favors reequilibration of melts produced in the lower part of the wedge when they pass through the hot core of the wedge. Grove et al. (2002) argued that melt moving by diffuse porous flow will reequilibrate with the hotter mantle dissolving silicate minerals and diluting $\mathrm{H}_{2} \mathrm{O}$ content. It will therefore appear to be a batch-melt in equilibrium with the mantle at the pressure and temperature from which it segregated. Our experimental results should therefore be interpreted in terms of a batch melt that records the pressure of last equilibration and an apparent melt fraction at that depth. The composition studied does therefore not record the depth of initiation of melting or the initial melt fraction.

The experimental composition studied was chosen, because of its very primitive geochemical characteristics and is interpreted to be close to the primary melt composition. In the batch melting scenario, the multiple saturation point occurs at the temperature and pressure at which the melt last equilibrated with the mantle source, and the phases stable at the multiple saturation point are the equilibrium phases left behind in the residue after melting. In this framework our data shows that the Mascota absarokites segregated from a harzburgitic mantle residue at a pressure of $1.6 \mathrm{GPa}$ or $1.7 \mathrm{GPa}$ and $1405^{\circ} \mathrm{C}$ or $1310^{\circ} \mathrm{C}$, if the pre-eruptive water content is $\sim 1.7$ or $\sim 5.1 \mathrm{wt} \% \mathrm{H}_{2} \mathrm{O}$ respectively (Figure $6 \mathrm{a} \& 6 \mathrm{~b}$ ). The pre-eruptive $\mathrm{H}_{2} \mathrm{O}$ content of the Mascota absarokites is not well known, a minimum value is the actual $\mathrm{H}_{2} \mathrm{O}$ content in the lavas, which ranges from $\sim 0.3$ to $\sim 0.95 \mathrm{wt} \%$. Most likely the initial $\mathrm{H}_{2} \mathrm{O}$ content was higher before magmatic dewatering during ascent (Sisson and Grove, 1993). Pre-eruptive $\mathrm{H}_{2} \mathrm{O}$ contents' for cogenetic rocks with hydrous phenocrysts have been estimated experimentally to be as high as $4.6 \mathrm{wt} \% \mathrm{H}_{2} \mathrm{O}$ (Carmichael et al., 1996). The actual $\mathrm{H}_{2} \mathrm{O}$ contents of our experiments are a product of $\mathrm{H}_{2} \mathrm{O}$ gain during processing in the case of the initially anhydrous composition MEX-1.7 and the limitation to a maximum of adding $5.1 \mathrm{wt} \% \mathrm{H}_{2} \mathrm{O}$ in the case of MEX-5.1. Given that the $\mathrm{H}_{2} \mathrm{O}$ content of the Mascota absarokites are not known, our experiments span a reasonable range in $\mathrm{H}_{2} \mathrm{O}$ contents. Since the lower temperatures produced by higher $\mathrm{H}_{2} \mathrm{O}$ contents are closer to the expected temperatures in the mantle wedge, we prefer the higher $\mathrm{H}_{2} \mathrm{O}$ content of $\sim 5.1$ wt\%.

The appearance of clinopyroxene just $30^{\circ} \mathrm{C}$ below the liquidus at the pressure of multiple saturation and $\mathrm{H}_{2} \mathrm{O}$ contents of $\sim 1.7$ wt\% indicates that absarokite M.102 is close to being saturated with a peridotitic assemblage of olivine, orthopyroxene and clinopyroxene. No aluminous phase (spinel) 
and no hydrous phases (e.g. phlogopite) are stable for the first $70^{\circ} \mathrm{C}$ below the liquidus at $\sim 1.7 \mathrm{wt} \%$ $\mathrm{H}_{2} \mathrm{O}$. The ol-cpx-plag projection in Figure 7 shows that our multiply saturated liquids are poor the plag component compared to dry melts in equilibrium with all mantle phases including an aluminous phase at $1.6 \mathrm{GPa}$ (Kinzler and Grove, 1992a). Plag is the only aluminous component in the projection, therefore indicating that our multiply saturated liquids do not contain enough $\mathrm{Al}_{2} \mathrm{O}_{3}$ to be saturated with an aluminous phase. Previous workers have argued for the presence of phlogopite in the source of the Mascota absarokites. The enrichment of incompatible elements that partition into the fluid but also into phlogopite ( $\mathrm{Ba}-\mathrm{Sr}-\mathrm{K})$ compared to incompatible elements that only partition into the fluid (B-Cs-U), indicates the participation of phlogopite in the element transfer from the slab to the melt (Hochstaedter et al., 1996). The strong positive correlation of $\mathrm{Ba}, \mathrm{Sr}$ and $\mathrm{K}$ with $\mathrm{TiO}_{2}$ in the potassic lavas have been interpreted as an incremental contribution of phlogopite/amphibole to the melt (Carmichael et al., 1996). The absence of phlogopite in our multiply saturated assemblages, is not inconsistent with the notion of a phlogopite bearing source. As we have argued above magmas rising through the inverted thermal structure of the wedge are likely to reequilibrate at lower pressures and higher temperatures. The phases present at the multiple saturation point are therefore and indication of the phases present at the depth of last reequilibration rather than the residue of the original melting process at greater depth. The major oxides $\mathrm{SiO}_{2}, \mathrm{MgO}, \mathrm{FeO}, \mathrm{CaO}$ and $\mathrm{Al}_{2} \mathrm{O}_{3}$ will therefore contain information about the bulk composition at the pressure of last equilibration, but the minor and trace elements might still retain information about the original source. We will refer to the bulk composition at the pressure of last equilibration, which can be inferred from major elements, as the major element source (MS), while the source retained in minor and trace elements will be called the original source (OS).

It is possible to estimate the major element source, by considering the multiply saturated melt as a batch melt from the pressure of last equilibration. In the batch melting model the source composition is a linear combination of the melt and the solid residue at the multiple saturation point. $C_{0}{ }^{i}=F C_{L}{ }^{i}+(1-F) C_{R}{ }^{i}$ where $F$ is the melt fraction, $C_{0}{ }^{i}$ is the concentration of oxide $i$ in the source, $C_{L}{ }^{i}$ is the concentration of oxide $i$ in the liquid and $C_{R}{ }^{i}$ is the concentration of oxide $i$ in the residue. In the batch melting equation commonly used in trace element modeling, the bulk distribution coefficient $D^{i}=C_{L}{ }^{i} / C_{R}{ }^{i}$ is used to eliminate the usually unknown concentration in the residue $C_{R}{ }^{i}$. At the multiple saturation point the concentrations of oxide $i$ in both the liquid $C_{L}{ }^{i}$ and the residue $C_{R}{ }^{i}$ are known from the analysis of the experimental products (Table 4\&5). Therefore, knowledge of the bulk distribution coefficient is not necessary to estimate the melt fraction $F$. In the case of more than one residual phase, $(1-F) C_{R}{ }^{i}=\Sigma\left(x_{P} C_{P}{ }^{i}\right)$ where $x_{P}$ is the modal fraction of phase $P$ in the residue and 
$C_{P}{ }^{i}$ is the concentration of oxide $i$ in the phase $P$, and the sum is of the total number of phases. So that the concentrations of the oxides in the multiple saturation phases can be related to the concentration in the source by the linear system $C_{0}{ }^{i}=F C_{L}{ }^{i}+\Sigma\left(x_{P} C_{P}{ }^{i}\right)$. Written in matrix form $A x=C_{0}$, where $A$ is a mxn matrix containing the composition of the multiple saturation phases as columns $\left(C_{L}{ }^{i}, C_{P}{ }^{i} s\right), x$ is the vector of phase proportions (including $F$ as one entry) and $C_{0}$ is an assumed major element source. This linear system is over determined, because the number of oxides (8) is larger than the number of phases (3). The overdetermined system does not have an explicit solution, but a solution $\chi$ that minimizes the error can be found using a least squares algorithm. Therefore, the degree of partial melting $F$ (melt fraction) can be estimated, if the correct major element source composition $C_{0}$ is known. Since the major element source composition is unknown, it is necessary to try a large number of possible source compositions and try to identify the one that gives best results. We have explored the variation of melt fraction with changes in major element source composition in Figure $9 \mathrm{a} \& 9 \mathrm{~b}$ (solid lines). We have varied the source composition $C_{0}$ linearly between the three relatively extreme Mexican peridotite xenoliths from Luhr and Arnanda Gomez (1997). The xenoliths composition vectors, which have been chosen to span the compositional space are the most fertile lherzolite $(L H Z)$, the most depleted harzburgite $(H Z)$ and the single phlogopite-lherzolite (PLHZ) in their collection, see Table 6 for compositions. Any major element source composition in the triangle in Figure $9 \mathrm{a} \& 9 \mathrm{~b}$ can be written $C_{0}=a H Z+b L H Z+c P L H Z$, where $a, b$ and $c$ have been varied from 0 to 1 under the constraint $a+b+c=1$. Note, although $P L H Z$ classifies as a lherzolite, it has only $\sim 7.5 \%$ wt of modal clinopyroxene, and is close to being a phlogopite-harzburgite. Although the composition of natural xenoliths is not generally a linear combination of these three compositions, a linear composition space is useful to show the effects of variable source composition on melt-fraction. In the batch melting model the correct major element source composition is a linear combination of the multiple saturation phases, and the mass balance should have no error. It is therefore possible to identify a potential major element source by a minimum in the error associated with the mass balance. Figures $9 a \& 9 b$ show the relative error in the mass balance in dashed lines. The absolute error is the length of error vector $\|e\|=\left\|C_{0}-p\right\|$, were $p$ is the best-fit model given by the mass balance $p=A \chi$. Since the oxides vary considerably in abundance, the error vector has been normalized by dividing element wise by composition $n=H Z / 3+L H Z / 3+P L H Z / 3$, to give all oxides similar weight. The relative error shown in Figure $9 \mathrm{a} \& 9 \mathrm{~b}$ is the length of this normalized error vector $\left\|e_{n}\right\|$. Since the calculated optimal source will depend on the error criterion that is chosen, the beșt-fit sources calculated using two other errors are shown. The left pointing triangle is the best-fit source given by the absolute 
error $\|e\|$, while the upward pointing triangle is a relative error $\left\|e_{c o l}\right\|$, were the error is normalized by the major element source composition $\left(C_{0}\right)$ in the mass balance. For both multiple saturation experiments D88 and B859, there is are well-defined and small minima with $\|e\|,\left\|e_{n}\right\|$ and $\left\|e_{C o}\right\|<1$, showing that the major element source is peridotitic material. The good match also increases our confidence in the batch melting assumption. Figures $9 \mathrm{a} \& 9 \mathrm{~b}$ show that the preferred source is a depleted therzolite or harzburgite, for all three measures of error. The PLHZ component in the major element source of reflects the high concentration of alkalis in particular potassium. Since phlogopite/amphibole is not stable at the pressure and temperature of multiple saturation (Figure 6a \& 6b) the PHLZ component has to be in the melt. The two optimal source compositions S-1.7 for the experiments with $1.7 \mathrm{wt} \% \mathrm{H}_{2} \mathrm{O}$ and S-5.1 for the experiments with $5.1 \mathrm{wt} \% \mathrm{H}_{2} \mathrm{O}$, are indicated by the black stars and given in Table 6. The apparent melt fractions calculated for melting of the optimal major element sources are smaller than $\sim 5 \%$ for both multiple saturation points and all measures of error.

A further test of the source composition is the composition of the residual phases. Figure 5 compares our clinopyroxenes (cpx's) to the compositions of residual cpx's that have been produced in mantle melting studies at pressures from $1.0 \mathrm{GPa}$ to $2.0 \mathrm{GPa}$, and the $\mathrm{CaO}$ and $\mathrm{Al}_{2} \mathrm{O}_{3}$ contents of our cpx's are very similar to peridotitic cpx's from multiple saturation and sandwich studies (Kinzler and Grove, 1992b; Gaetani and Grove, 1998; Robinson et al., 1998). The temperature of experiment B833, with $5.1 \mathrm{wt} \% \mathrm{H}_{2} \mathrm{O}$ is much lower and the cpx is $\sim 2.5 \mathrm{wt} \%$ more calcic, this effect is also observed in the cpx compositions between anhydrous and hydrous experiments of Gaetani \& Grove (1998). There is a systematic difference between the cpx's produced in forward peridotite melting experiments (Pickering-Witter and Johnston, 2000; Schwab and Johnston, 2001) and inverse basaltperidotite multiple saturation experiments (Kinzler and Grove, 1992a; Gaetani and Grove, 1998; Robinson et al., 1998). The forward melting experiments used natural minerals as their starting materials, while most inverse experiments mainly used synthetic oxide mixes or powders of natural glasses, the difference might be caused by unreacted mineral cores in experiments using natural minerals as starting materials (Falloon et al., 1999). The compositional similarity of our cpx compositions to cpx's from studies of peridotite melting suggests that the source of absarokite M.102 is peridotitic.

Assuming batch melting, our experimental results are strong evidence, that absarokite M.102 has segregated from a harzburgite, at a pressure from $1.6 \mathrm{GPa}$ to $1.7 \mathrm{GPa}$ and temperature of $1400^{\circ} \mathrm{C}$ to $1300^{\circ} \mathrm{C}$, depending on the $\mathrm{H}_{2} \mathrm{O}$ content from $\sim 1.7 \mathrm{wt} \%$ to $\sim 5.1 \mathrm{wt} \%$. The preferred major element 
source composition is a depleted lherzolite or harzburgite and the apparent degree of partial melting is smaller than $5 \mathrm{wt} \%$.

\section{Discussion}

Our experimental results provide direct constraints on the depth of origin of potassic lavas, and mantle temperatures beneath the Jalisco block. The pressure and temperature of origin of minettes from several localities on the Jalisco block have been estimated using $\mathrm{BaO}$ and $\mathrm{TiO}_{2}$ exchange between phlogopite and liquid (Righter and Carmichael, 1996). Figure 10 compares our results with those from the minettes and spinel-peridotite xenoliths. Our multiple saturation pressures of 1.6 to 1.7 GPa are similar to the highest pressure estimates from the minettes in the Colima rift. These pressures are twice as high as the $0.8 \mathrm{GPa}$ pressure inferred for the absarokites by Righter et al. 2000 , using the Ol-Cpx-Qtz-Ne pseudo-ternary projection (Sack et al., 1987). Our estimates of the depth of last equilibration at a depth of $48-51 \mathrm{~km}$ are well within the mantle wedge. The absarokites studied here have not ponded at the base of the crust $(\sim 35-40 \mathrm{~km})$ (Urrutia-Fugugauchi and FlorezRuiz, 1996), unlike many calc-alkaline (Lange and Carmichael, 1991), lamprophyric (Righter and Carmichael, 1996) and alkaline melts (Righter et al., 1995) in the area. Our temperature estimates strongly depend on the initial $\mathrm{H}_{2} \mathrm{O}$ content of the melts, but are higher than both the estimates from the minettes and xenoliths at same pressures. Assuming that the pressure and temperature of multiple saturation changes linearly with increasing $\mathrm{H}_{2} \mathrm{O}$ content, the change in the pressure and temperature of multiple saturation with $\mathrm{H}_{2} \mathrm{O}$ content can be estimated. $\mathrm{H}_{2} \mathrm{O}$ contents of $\sim 8.3$ wt $\%$ are necessary to lower the temperatures to the level of the hottest temperature estimates for the minettes from the Los Volcanoes volcanic field, just south of the Mascota volcanic field (Figure 10). The subduction history of the Rivera plate is very complex, and the thermal structure of the mantle wedge is likely to be different subduction zones with simpler history and geometry. Therefore our direct temperature estimates from multiple saturation studies are important constraints on the thermal structure of the mantle wedge beneath the Jalisco block. They indicate that parts of the mantle wedge might be hotter than previously assumed.

The liquidus relations similar to those presented above have been interpreted in the literature either to indicate a pervasively metasomatised phlogopite-harzburgite source (Tatsumi and Koyaguchi, 1989) or a peridotite host rock with localized veins of phlogopite, amphibole, and mainly clinopyroxene (Foley, 1993). In his model for the formation of lamprophyre magmas, Foley (1992b) has proposed that melting is initially restricted to the incompatible element and volatile-rich vein. This vein-melt then dissolves minerals from the wall rock, assumed to be a lherzolite. At the time of melt segregation only phlogopite is left in the vein assemblage and only the olivine and 
orthopyroxene are left in the wall rock that is in contact with the melt. Therefore the melt appears to be in equilibrium with a phlogopite-harzburgite, despite its origin from a veined lherzolite. In the case of the absarokite studied here the vein/wall rock-ratio would be very small, so that the major elements indicate equilibrium with a harzburgite, but the trace elements still show a diluted vein signature.

The three major reasons to postulate a veined mantle rather than a more homogeneously enriched mantle are: 1) the existence of veined mantle xenoliths (Irving, 1980; Vidal et al., 1989; Obrien et al., 1991; Gregoire et al., 2002); 2) a number of experimental studies on highly potassic compositions that are not equilibrated with orthopyroxene and olivine on their liquidus at any pressure (Edgar et al., 1976; Barton and Hamilton, 1979; Edgar et al., 1980; Arima and Edgar, 1983b); 3) arguments suggesting the localized movement of metasomatic agents along brittle fractures (Sleep, 1988), rather then in porous channels (Spiegelman et al., 2001) or as solitary waves (Nakayama and Mason, 1999) or by pervasive porous flow.

One phlogopite-clinopyroxenite xenolith has been reported from an augite minette flow in the Jalisco block, but it has been interpreted as a cumulate formed during fractionation of a more primitive minette parent (Righter and Rosas Elguera, 2001). There are two experimental studies on Western Mexican potassic rocks, one on olivine and augite minettes that is limited to crustal pressures (Righter and Carmichael, 1996), and the present study on a sodic absarokite that indicates reequilibration with a depleted lherzolite or harzburgite. Also the mechanism, by which the metasomatic agent passes trough the mantle wedge is speculative. Although experimental data on $\mathrm{H}_{2} \mathrm{O}$ connectivity exists over a large range of pressures and temperatures (Watson and Brenan, 1987; Mibe et al., 1998;1999), there is currently no data on the highly and alkaline and potentially saline fluids that are thought to leave the slab (Stolper and Newman, 1994; Shmulovich and Graham, 1996; Grove et al., 2002).

Geochemical studies have favored a veined mantle as the original source of the potassic rocks in the Mascota area (Carmichael et al., 1996) and the Jalisco block in general (Luhr, 1997). Again it is important to separate the original source indicated by trace and minor elements from the major element source indicated by our experiments. So that there are really two questions, does the major element source contain veins of non-peridotitic material and did the original source of the magma contain veins. Using the same technique as above we have tested if non-peridotitic veins in the major element source are consistent with mass balance constraints, for a limited number of vein compositions (Figure 11). We have chosen HZ (Table 6), Lloyd's phlogopite-clinopyroxenite (Lloyd et al., 1985)and a cratonic glimmerite (Gregoire et al., 2002) to span a compositional space that simulates veined harzburgite. Figure 11 shows that even small amounts of non-peridotitic 
material, lead to very large errors $(\|\mathrm{e}\|>10)$ and therefore veins of the chosen compositions are unlikely to be present in the major element source of the absarokite studied here. Also the residual cpx compositions from the only available study of the melting of a phlogopite-clinopyroxenite vein at 2.0 and $3.0 \mathrm{GPa}$ (Lloyd et al., 1985), are $\sim 9 \mathrm{wt} \%$ higher in $\mathrm{CaO}$ than in our experiments with $1.7 \mathrm{wt} \% \mathrm{H}_{2} \mathrm{O}$, and $\sim 5.1 \mathrm{wt} \%$ higher than the cpx from experiment $\mathrm{B} 833$ with $5.1 \mathrm{wt} \% \mathrm{H}_{2} \mathrm{O}$ (Figure 5). The clinopyroxenes in the residue of a phlogopite-clinopyroxenite also have much lower $\mathrm{Al}_{2} \mathrm{O}_{3}$ contents, than cpx's in this study and multiple saturation experiments. The compositional similarity of our cpx compositions to cpx's from studies of peridotite melting and the difference in cpx compositions between our study and a liquidus study, multiply saturated with olivineclinopyroxenite and also a clinopyroxenite melting study, suggests that the source of absarokite M.102 is peridotitic.

Whether veins or dispersed phlogopite/amphibole was present in the original source where the mantle first melted cannot be assessed with available geochemical data. A simple question that can be addressed is, can a reasonable degree of melting of a phlogopite lherzolite or phlogopite harzburgite produce the enrichments in incompatible elements observed in the Mascota absarokites. Figure 12 shows the difference $\Delta$ between concentrations of $\mathrm{Ba}, \mathrm{Rb}, \mathrm{Sr}, \mathrm{Nb}$ and $\mathrm{Y}$ observed in average Mascota absarokites $(\langle\mathrm{Ba}\rangle=1912,\langle\mathrm{Rb}\rangle=27,\langle\mathrm{Sr}\rangle=2224,\langle\mathrm{Nb}\rangle=9.8,\langle\mathrm{Y}\rangle=19.2)$ and $5 \%$ batch melts from four different sources. Sources compositions range from a depleted upper mantle (DM) to strongly enriched phlogopite peridotite (PP max, (Erlank et al., 1987)). A positive $\Delta$ indicates that the source cannot produce the concentration observed in the lavas at the given melt fraction. A negative $\Delta$ indicates that the partial melting of the source can produce incompatible element abundances even higher than observed in the lavas. Figure 12 shows that the $\Delta$ decreases for $\mathrm{Ba}, \mathrm{Rb}, \mathrm{Sr}$ and $\mathrm{Nb}$ with increasing metasomatism of the source. At reasonably low melt fractions $(\sim 5 \%)$ average phlogopite peridotites (PP ave) can supply the incompatible element abundances observed in the absarokites. Therefore both veined and more homogeneously enriched mantle are possible original sources for the Mascota absarokites. The petrogenetic model for the Mascota absarokites would therefore involve two steps, first the melting of an incompatible element enriched source at depth and a later equilibration with a depleted lherzolite or harzburgite at shallower depth in the mantle.

Our major element model indicates both low apparent melt fractions and a depleted major element source, suggesting that the major element source has been depleted by a previous partial melting event. A depleted harzburgitic source is also in agreement with geochemical and other experimental observations suggesting a depleted source. The main geochemical argument is the characteristic 
depletion of immobile, incompatible elements, such as the HFSE in calc-alkaline lavas relative to average mid ocean ridge basalt (MORB) (Pearce et al., 1977). Partial melting is thought to deplete the source of calc-alkaline magmas relative to the MORB source. In the Cascades, the experimental work by Bartels et al. (1991) has identified HAOT's as the products of this prior partial melting event. HAOT's are saturated with a lherzolite source under anhydrous conditions near the top of the mantle wedge, and interpreted to form during 6-10\% decompression melting of spinel peridotite, dragged into the mantle wedge leaving behind a depleted lherzolite or harzburgite.

No HAOT have been reported from the Western Mexican volcanic belt (Righter, 2000). Instead the intraplate alkaline lavas in the Western Mexican volcanic belt have been interpreted as products of shallow decompression melting as asthenosphere is drawn into the mantle wedge (Hochstaedter et al., 1996; Luhr, 1997). However, differences between the intraplate alkaline basalts and calcalkaline and potassic lavas, in $\mathrm{Ba}-\mathrm{Ti}$ trends, HFSE abundances and $\mathrm{Sr}-\mathrm{Nd}$ isotopic compositions suggest different mantle sources (Luhr, 1997). Therefore the intraplate alkaline lavas cannot be the product of the partial melting process that produces the depleted source of the Mascota absarokites. To date no lavas have been identified in the Western Mexican volcanic belt that point to decompression melting of a MORB source mantle, yet the experimental evidence presented above requires such a depleted source. It has been suggested that the metasomatism producing the lamprophyres is older than the current subduction process, and might date to the Tertiary Sierra Madre Occidental magmatism (Hochstaedter et al., 1996; Righter and Rosas Elguera, 2001). One might also speculate that the depletion producing the harzburgitic source is older than the current subduction process.

\section{Conclusion: Origin of Pliocene-Holocene absarokites in the Mascota graben}

1) The Mascota absarokites have segregated from a depleted lherzolite or harzburgite residue at a pressure of 1.6-1.7 GPa ( 48-51 km depth) in the spinel-peridotite stability field. They have not ponded and fractionated at the crust mantle interface (35-40 km depths) or in the crust as previously assumed. They have retained the memory of the depth of segregation, and are therefore powerful constraints on temperature in the mantle wedge at the time of their formation. They record temperatures of $1310^{\circ} \mathrm{C}$ at a pressure of $1.7 \mathrm{GPa}$ depending on pre eruptive $\mathrm{H}_{2} \mathrm{O}$ content of 5.1 wt\%.

2) The apparent melt fraction of the of the Mascota absarokites at the pressure of last equilibration is less than $5 \%$ batch melting, significantly lower than the 5-20\% melt fractions estimated for calcalkaline lavas. A small degree of melting of an original phlogopite peridotite at greater depth can produce the concentrations of $\mathrm{Ba}, \mathrm{Rb}$ and $\mathrm{Sr}$ observed in the Mascota absarokites. A small melt 
fraction of the original source can also explain the enrichment in HFSE relative to calc-alkaline lavas.

3) The presence of non peridotitic veins at the pressure of last equilibration is not consistent with mass balance. In subduction zones magmas are likely to reequilibrate as they pass through the mantle wedge. Therefore liquidus phase relations are unlikely to record the presence of veins in the original source. The $\mathrm{Ba}, \mathrm{Rb}$ and $\mathrm{Sr}$ concentrations recorded in the Mascota absarokites are consistent with either a veined or a pervasively enriched original source.

Figure 13 illustrates our model for the formation of the Mascota absarokites. Depleted harzburgitic mantle is dragged around the corner and metasomatised by fluids ascending from the slab. The slab component hydrates the mantle, forming phlogopite and amphibole. As the hydrated mantle descends with the slab, the temperature and pressure increase until the hydrous phases become unstable and a $\mathrm{Na}, \mathrm{K}, \mathrm{Ba}, \mathrm{Rb}$ and $\mathrm{Sr}$ rich fluid is released (Davies and Stevenson, 1992). The fluid migrates upwards until the temperatures exceed the hydrous solidus, and a highly potassic melt forms. This melt ascends through the mantle wedge reequilibrating with the hotter shallower mantle, by dissolving silicate minerals and diluting its $\mathrm{H}_{2} \mathrm{O}$ content. At a pressure of to $1.7 \mathrm{GPa}$ the melt reequilibrates last with the mantle recording a melt fraction of less than $5 \%$ batch melting. The melt is then transported to the surface without apparent modification. The extensional tectonics of the area might facilitate the melt transport through the crust. 


\section{References}

Allan JF (1986). "Geology of the Northern Colima and Zacoalco Grabens, Southwest Mexico - Late Cenozoic Rifting in the Mexican Volcanic Belt." Geological Society of America Bulletin 97(4): 473485 .

Arima M and Edgar AD (1983b). "High-Pressure Experimental Studies on a Katungite and Their Bearing on the Genesis of Some Potassium-Rich Magmas of the West Branch of the African Rift." Journal of Petrology 24(2): 166-187.

Armstrong JT (1995). "Citzaf - a Package of Correction Programs for the Quantitative Electron Microbeam X-Ray-Analysis of Thick Polished Materials, Thin-Films, and Particles." Microbeam Analysis 4(3): 177-200.

Atwater T (1970). "Implications of plate tectonics for the Cenozoic tectonic evolution of western North America." Geological Society of America Bulletin 81: 3513-3536.

Baker MB, Grove TL and Price R (1994). "Primitive Basalts and Andesites from the Mt Shasta Region, N California - Products of Varying Melt Fraction and Water- Content." Contributions to Mineralogy and Petrology 118(2): 111-129.

Baker MB and Stolper EM (1994). "Determining the Composition of High-Pressure Mantle Melts Using Diamond Aggregates." Geochimica Et Cosmochimica Acta 58(13): 2811-2827.

Barton M and Hamilton DL (1979). "Melting Relationships of a Madupite from the Leucite Hills, Wyoming, to $30 \mathrm{~Kb}$." Contributions to Mineralogy and Petrology 69(2): 133-142.

Boyd FR and England JL (1960). "Apparatus for phase equilibrium studies at pressures up to $50 \mathrm{kbar}$ and temperatures up to 1750C." Journal of Geophysical Research-Solid Earth and Planets 65: 741748.

Carmichael ISE, Lange RA and Luhr JF (1996). "Quaternary minettes and associated volcanic rocks of Mascota, western Mexico: A consequence of plate extension above a subduction modified mantle wedge." Contributions to Mineralogy and Petrology 124(3-4): 302-333.

Davies JH and Stevenson DJ (1992). "Physical Model of Source Region of Subduction Zone Volcanics." Journal of Geophysical Research-Solid Earth 97(B2): 2037-2070.

DeMets C and Traylen S (2000). "Motion of the Rivera plate since $10 \mathrm{Ma}$ relative to the Pacific and North American plates and the mantle." Tectonophysics 318(1-4): 119-159.

Edgar AD, Condliffe E, Barnett RL and Shirran RJ (1980). "An Experimental-Study of an Olivine Ugandite Magma and Mechanisms for the Formation of Its K-Enriched Derivatives." Journal of Petrology 21(3): 475-497.

Edgar AD, Green DH and Hibberson WO (1976). "Experimental Petrology of a Highly Potassic Magma." Journal of Petrology 17(3): 339-356. 
Elkins Tanton LT and Grove TL Evidence for the formation of Pliocene Sierran high-potassium magmas from deep melting of an olovine-spinel-phlogopite-clinopyroxenite.

Elkins Tanton LTE, Grove TL and Donnelly-Nolan J (2001). "Hot, shallow mantle melting under the Cascades volcanic arc." Geology 29(7): 631-634.

Erlank AJ, Waters FG, Hawkesworth CJ, Haggerty SE, Allsopp HL, S. RR and Menzies MA (1987). Evidence for Mantle Metasomatism in Peridotite Nodules from the Kimberly Pipes, South Africa. Mantle Metasomatism. Menzies MA and Hawkesworth CJ. London, Academic Press Inc. (London) LTD. 2: 472.

Falloon TJ, Green DH, Danyushevsky LV and Faul UH (1999). "Peridotite melting at 1 center dot 0 and 1 center dot $5 \mathrm{GPa}$ : an experimental evaluation of techniques using diamond aggregates and mineral mixes for determination of near-solidus melts." Journal of Petrology 40(9): 1343-1375.

Ferrari I, Garduno VH, Pasquare G and Tibaldi A (1994). "Volcanic and tectonic evolution of central Mexico: Oligocene to Present." Geofis. Int. 33: 91-105.

Foley S (1992a). "Petrological Characterization of the Source Components of Potassic Magmas Geochemical and Experimental Constraints." Lithos 28(3-6): 187-204.

Foley S (1992b). "Vein-Plus-Wall-Rock Melting Mechanisms in the Lithosphere and the Origin of Potassic Alkaline Magmas." Lithos 28(3-6): 435-453.

Foley SF (1993). "An Experimental-Study of Olivine Lamproite - 1st Results from the Diamond Stability Field." Geochimica Et Cosmochimica Acta 57(2): 483-489.

Gaetani GA and Grove TL (1998). "The influence of water on melting of mantle peridotite." Contributions to Mineralogy and Petrology 131(4): 323-346.

Gill J (1981). "Orogenic Andesites and Plate Tectonics." Springer Verlag.

Gregoire M, Bell DR and Le Roex AP (2002). "Trace element geochemistry of phlogopite-rich mafic mantle xenoliths: their classification and their relationship to phlogopite-bearing peridotites and kimberlites revisited." Contributions to Mineralogy and Petrology 142(5): 603-625.

Grove TL (1993). "Corrections to expressions for calculating mineral components in "Origin of Calc-Alkaline Series Lavas at Medicine Lake Volcano by Fractionation, Assimilation and Mixing" and "Experimental Petrology of normal MORB near the Kane Fracture Zone: $22^{\circ}-25^{\circ} \mathrm{N}$, midAtlantic ridge"." Contributions to Mineralogy and Petrology 114: 422-424.

Grove TL and Bence AE (1977). "Experimental study of pyroxene-liquid interaction in quartznormative basalt 15597." Proc. Lunar Sci. Conf. 8: 1549-1579.

Grove TL and Juster TC (1989). "Experimental Investigations of Low-Ca Pyroxene Stability and Olivine Pyroxene Liquid Equilibria at 1-Atm in Natural Basaltic and Andesitic Liquids."

Contributions to Mineralogy and Petrology 103(3): 287-305. 
Grove TL, Parman SW, Bowring SA, Price RC and Baker MB (2002). "The role of an H2O-rich fluid component in the generation of primitive basaltic andesites and andesites from the Mt. Shasta region, N California." Contributions to Mineralogy and Petrology 142(4): 375-396.

Hays JF (1966). "Lime-alumina-silica." Carnegie Institution Washington Yearbook 65: 234-239.

Hochstaedter AG, Ryan JG, Luhr JF and Hasenaka T (1996). "On B/Be ratios in the Mexican Volcanic Belt." Geochimica Et Cosmochimica Acta 60(4): 613-628.

Iddings JP (1895). "Absarokite-shoshonite-bankanite series." Journal of Geology 3(935-959).

Irving AJ (1980). "Petrology and Geochemistry of Composite Ultramafic Xenoliths in Alkalic Basalts and Implications for Magmatic Processes within the Mantle." American Journal of Science 280A: 389-426.

Johannes W, Bell PM, Mao HK, Boettcher AL, Chipman DW, Hays JF, newton RC and Seifert F (1971). "An Interlaboratory comparison of piston-cylinder pressure calibration using the albitebreakdown reaction." Contributions to Mineralogy and Petrology 32: 24-38.

Johnson KTM, Dick HJB and Shimizu N (1990). "Melting in the Oceanic Upper Mantle - an Ion Microprobe Study of Diopsides in Abyssal Peridotites." Journal of Geophysical Research-Solid Earth and Planets 95(B3): 2661-2678.

Khutorskoy MD, Degalo-Argote LA, Kononov VI and Polyak BG (1994). "Tectonics of the offshore Manzanillo and Tepcan basins, Mexican Pacific, from heat flow, bathymetric and seismic data." Geofisica International 33: 161-185.

Kinzler RJ (1997). "Melting of mantle peridotite at pressures approaching the spinel to garnet transition: Application to mid-ocean ridge basalt petrogenesis." Journal of Geophysical ResearchSolid Earth 102(B1): 853-874.

Kinzler RJ and Grove TL (1992a). "Primary Magmas of Midocean Ridge Basalts .1. Experiments and Methods." Journal of Geophysical Research-Solid Earth 97(B5): 6885-6906.

Kinzler RJ and Grove TL (1992b). "Primary Magmas of Mid-Ocean Ridge Basalts 2. Applications." Journal of Geophysical Research 97: 6907-6926.

Lange RA and Carmichael ISE (1991). "A Potassic Volcanic Front in Western Mexico - the Lamprophyric and Related Lavas of San-Sebastian." Geological Society of America Bulletin 103(7): 928-940.

Lloyd FE, Arima M and Edgar AD (1985). "Partial Melting of a Phlogopite-Clinopyroxenite Nodule from Southwest Uganda - an Experimental-Study Bearing on the Origin of Highly Potassic Continental Rift Volcanics." Contributions to Mineralogy and Petrology 91(4): 321-329.

Luhr JF (1997). "Extensional tectonics and the diverse primitive volcanic rocks in the western Mexican Volcanic Belt." Canadian Mineralogist 35: 473-500. 
Luhr JF and Aranda Gomez JJ (1997). "Mexican peridotite xenoliths and tectonic terranes:

Correlations among vent location, texture, temperature, pressure, and oxygen fugacity." Journal of Petrology 38(8): 1075-1112.

Mibe K, Fujii T and Yasuda A (1998). "Connectivity of aqueous fluid in the Earth's upper mantle." Geophysical Research Letters 25(8): 1233-1236.

Mibe K, Fujii T and Yasuda A (1999). "Control of the location of the volcanic front in island arcs by aqueous fluid connectivity in the mantle wedge." Nature 401(6750): 259-262.

Molina-Garza R and Urrutia-Fucugauchi J (1993). "Deep-Crustal Structure of Central Mexico Derived from Interpretation of Bouguer Gravity-Anomaly Data." Journal of Geodynamics 17(4): 181-201.

Moore G, Marone C, Carmichael ISE and Renne P (1994). "Basaltic Volcanism and Extension near the Intersection of the Sierra-Madre Volcanic Province and the Mexican Volcanic Belt." Geological Society of America Bulletin 106(3): 383-394.

Morrison GW (1980). "Characteristics and Tectonic Setting of the Shoshonite Rock Association." Lithos 13(1): 97-108.

Nakayama M and Mason DP (1999). "Perturbation solution for small amplitude solitary waves in two-phase fluid flow of compacting media." Journal of Physics a-Mathematical and General 32(35): 6309-6320.

Nicholls J and Carmichael ISE (1969). "A commentary on the Absarokite-Shoshonite-Bankanite series of Wyoming, USA." Schweitzer Mineralogische und Petrologische Mitteilungen 49: 47-64.

Obrien HE, Irving AJ and McCallum IS (1991). "Eocene Potassic Magmatism in the Highwood Mountains, Montana - Petrology, Geochemistry, and Tectonic Implications." Journal of Geophysical Research-Solid Earth and Planets 96(B8): 13237-13260.

Pardo M and Suarez G (1993). "Steep Subduction Geometry of the Rivera Plate beneath the Jalisco Block in Western Mexico." Geophysical Research Letters 20(21): 2391-2394.

Pardo M and Suarez G (1995). "Shape of the Subducted Rivera and Cocos Plates in Southern Mexico - Seismic Anti Tectonic Implications." Journal of Geophysical Research-Solid Earth 100(B7): 12357-12373.

Pearce TH, Gorman BE and Birkett TC (1977). "Relationship between Major Element Chemistry and Tectonic Environment of Basic and Intermediate Volcanic-Rocks." Earth and Planetary Science Letters 36(1): 121-132.

Peccerillo A and Taylor SR (1976). "Geochemistry of Eocene Calc-Alkaline Volcanic-Rocks from Kastamonu Area, Northern Turkey." Contributions to Mineralogy and Petrology 58(1): 63-81.

Pickering-Witter J and Johnston AD (2000). "The effects of variable bulk composition on the melting systematics of fertile peridotitic assemblages." Contributions to Mineralogy and Petrology 140(2): 190-211. 
Rapp RP, Shimizu N, Norman MD and Applegate GS (1999). "Reaction between slab-derived melts and peridotite in the mantle wedge: experimental constraints at $3.8 \mathrm{GPa}$." Chemical Geology 160(4): 335-356.

Righter K (2000). "A comparison of basaltic volcanism in the Cascades and western Mexico: compositional diversity in continental arcs." Tectonophysics 318(1-4): 99-117.

Righter K and Carmichael ISE (1992). "Hawaiites and Related Lavas in the Atenguillo Graben, Western Mexican Volcanic Belt." Geological Society of America Bulletin 104(12): 1592-1607.

Righter K and Carmichael ISE (1996). "Phase equilibria of phlogopite lamprophyres from western Mexico: Biotite-liquid equilibria and P-T estimates for biotite-bearing igneous rocks." Contributions to Mineralogy and Petrology 123(1): 1-21.

Righter K, Carmichael ISE, Becker TA and Renne PR (1995). "Pliocene-Quaternary Volcanism and Faulting at the Intersection of the Gulf of California and the Mexican Volcanic Belt." Geological Society of America Bulletin 107(5): 612-626.

Righter K and Rosas Elguera J (2001). "Alkaline Lavas in the Volcanic Front of the Western Mexican Volcanic Belt: Geology and Petrology of the Ayutla and Tapalpa Volcanic Fields." Journal of Petrology 42(12): 2333-2361.

Righter K and Rosas-Elguera J (2001). "Alkaline lavas in the volcanic front of the western Mexican Volcanic Belt: Geology and petrology of the Ayutla and Tapalpa volcanic fields." Journal of Petrology 42(12): 2333-2361.

Robinson JAC, Wood BJ and Blundy JD (1998). "The beginning of melting of fertile and depleted peridotite at 1.5 GPa." Earth and Planetary Science Letters 155(1-2): 97-111.

Rosas Elguera J, Ferrari L, Garduno Monroy VH and Urrutia Fucugauchi J (1996). "Continental boundaries of the Jalisco block and their influence in the Pliocene-Quaternary kinematics of western Mexico." Geology 24(10): 921-924.

Rose EF, Shimizu N, Layne GD and Grove TL (2001). "Melt production beneath Mt. Shasta from boron data in primitive melt inclusions." Science 293(5528): 281-283.

Sack RO, Walker D and Carmichael ISE (1987). "Experimental Petrology of Alkalic Lavas Constraints on Cotectics of Multiple Saturation in Natural Basic Liquids." Contributions to Mineralogy and Petrology 96(1): 1-23.

Schwab BE and Johnston AD (2001). "Melting systematics of modally variable, compositionally intermediate peridotites and the effects of mineral fertility." Journal of Petrology 42(10): 1789-1811.

Shmulovich $\mathrm{KI}$ and Graham CM (1996). "Melting of albite and dehydration of brucite in $\mathrm{H} 2 \mathrm{O}-\mathrm{NaCl}$ fluids to 9 kbars and 700-900 degrees C: Implications for partial melting and water activities during high pressure metamorphism." Contributions to Mineralogy and Petrology 124(3-4): 370-382.

Sisson TW and Bronto S (1998). "Evidence for pressure-release melting beneath magmatic arcs from basalt at Galunggung, Indonesia." Nature 391(6670): 883-886. 
Sisson TW and Grove TL (1993). "Temperatures and H2o Contents of Low-Mgo High-Alumina Basalts." Contributions to Mineralogy and Petrology 113(2): 167-184.

Sleep NH (1988). "Tapping of Melt by Veins and Dikes." Journal of Geophysical Research-Solid Earth and Planets 93(B9): 10255-10272.

Spiegelman M, Kelemen PB and Aharonov E (2001). "Causes and consequences of flow organization during melt transport: The reaction infiltration instability in compactible media." Journal of Geophysical Research-Solid Earth 106(B2): 2061-2077.

Stolper E and Newman S (1994). "The Role of Water in the Petrogenesis of Mariana Trough Magmas." Earth and Planetary Science Letters 121(3-4): 293-325.

Suarez G, Garciaacosta V and Gaulon R (1994). "Active Crustal Deformation in the Jalisco Block, Mexico - Evidence for a Great Historical Earthquake in the 16th-Century." Tectonophysics 234(1-2): 117-127.

Tatsumi Y and Koyaguchi T (1989). "An Absarokite from a Phlogopite Iherzolite Source." Contributions to Mineralogy and Petrology 102(1): 34-40.

Umutia-Fugugauchi J and Florez-Ruiz JH (1996). "Bouger Gravity Anomalies and Regional Crustal Structure in Central Mexico." International Geology Review 38: 176-194.

Vidal P, Dupuy C, Maury R and Richard M (1989). "Mantle Metasomatism above Subduction Zones - Trace-Element and Radiogenic Isotope Characteristics of Peridotite Xenoliths from Batan Island (Philippines)." Geology 17(12): 1115-1118.

Watson EB and Brenan JM (1987). "Fluids in the Lithosphere .1. Experimentally-Determined Wetting Characteristics of Co2-H2o Fluids and Their Implications for Fluid Transport, Host-Rock Physical-Properties, and Fluid Inclusion Formation." Earth and Planetary Science Letters 85(4): 497515. 
Tables

Table 1. Experimental starting compositions

\begin{tabular}{|c|c|c|c|c|}
\hline oxide & M.102 & $\begin{array}{c}\text { MEX }-1.7^{b} \\
n=56\end{array}$ & $\begin{array}{c}\text { MEX-5. } 1^{c} \\
n=138\end{array}$ & $\begin{array}{c}\text { average } \\
\text { absarokite }\end{array}$ \\
\hline $\mathrm{SiO}_{2}$ & 49.40 & $48.83(52)$ & $47.89(49)$ & 50.62 \\
\hline $\mathrm{TiO}_{2}$ & 0.99 & $0.91(09)$ & $0.92(08)$ & 0.83 \\
\hline $\mathrm{Al}_{2} \mathrm{O}_{3}$ & 14.84 & $14.55(20)$ & $14.64(26)$ & 16.01 \\
\hline $\mathrm{FeO}^{*}$ & 7.63 & $7.91(15)$ & $7.76(16)^{e}$ & 8.25 \\
\hline $\mathrm{MnO}$ & 0.12 & $0.08(05)$ & $0.11(3)$ & 0.17 \\
\hline $\mathrm{MgO}$ & 11.63 & $12.42(20)$ & $11.87(16)$ & 6.24 \\
\hline $\mathrm{CaO}$ & 8.30 & $8.66(17)$ & $7.98(15)$ & 9.26 \\
\hline $\mathrm{Na}_{2} \mathrm{O}$ & 3.53 & $3.29(19)$ & $3.59(15)$ & 2.93 \\
\hline $\mathrm{K}_{2} \mathrm{O}$ & 1.40 & $1.21(05)$ & $1.18(03)$ & 2.74 \\
\hline $\mathrm{P}_{2} \mathrm{O}_{5}$ & 0.44 & $0.36(07)$ & $0.34(05)$ & 0.44 \\
\hline total & 98.28 & $98.47(81)$ & $95.88(67)$ & 97.49 \\
\hline $\begin{array}{c}\text { preferred } \\
\mathrm{H}_{2} \mathrm{O} \\
\end{array}$ & & 1.7 & 5.1 & \\
\hline Mg \# & 0.73 & 0.74 & 0.74 & 0.57 \\
\hline $\mathrm{Na}_{2} \mathrm{O}+\mathrm{K}_{2} \mathrm{O}$ & 4.93 & 4.50 & 4.77 & 5.67 \\
\hline $\mathrm{K}_{2} \mathrm{O} / \mathrm{Na}_{2} \mathrm{O}$ & 0.40 & 0.37 & 0.33 & 0.94 \\
\hline $\mathrm{Cr}$ & 460 & - & 13 & 156 \\
\hline $\mathrm{NiO}$ & 371 & - & 1060 & 50 \\
\hline
\end{tabular}

a target composition M.102 from Carmichael et al. 1996

b experimental bulk composition $\sim 1.7 \mathrm{wt} \% \mathrm{H}_{2} \mathrm{O}$, average of 56 electron microprobe analyses of glasses produced in superliquidus runs of experiments D87, D90 \& D127. Standard deviation in terms of last digits is given in brackets.

c experimental bulk composition with $\sim 5.1 \mathrm{wt} \% \mathrm{H}_{2} \mathrm{O}$, average of 138 analyses off wet glasses in superliquidus runs (B848, B854, $\mathrm{B} 855$ \& $\mathrm{B} 856$ ). Standard deviation in terms of last digits is given in brackets.

average absarokite from Morrison (1980)

e For FeO in MEX-5.1 run B848 was excluded see text for discussion $(\mathbf{n}=90)$ 


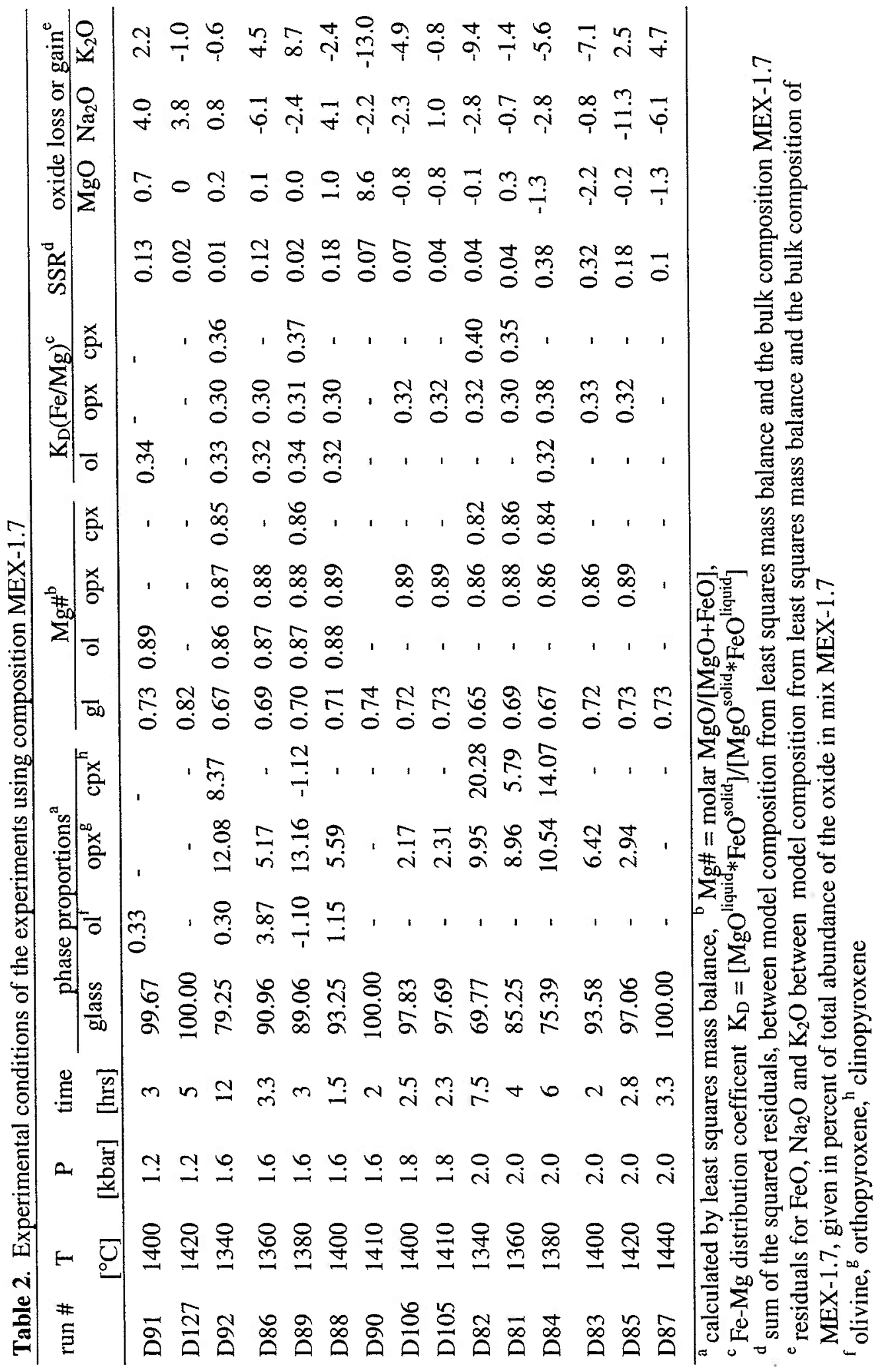




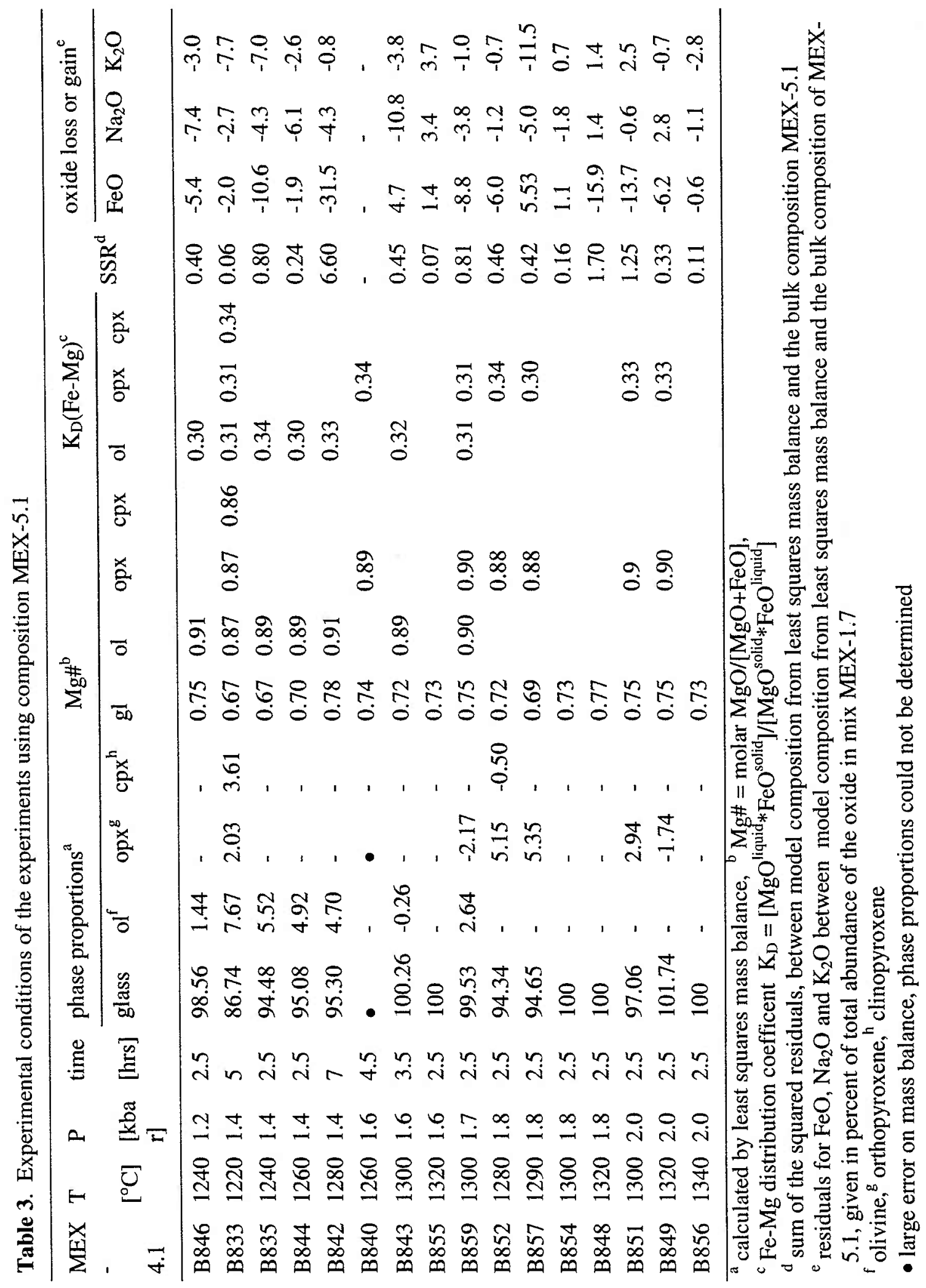




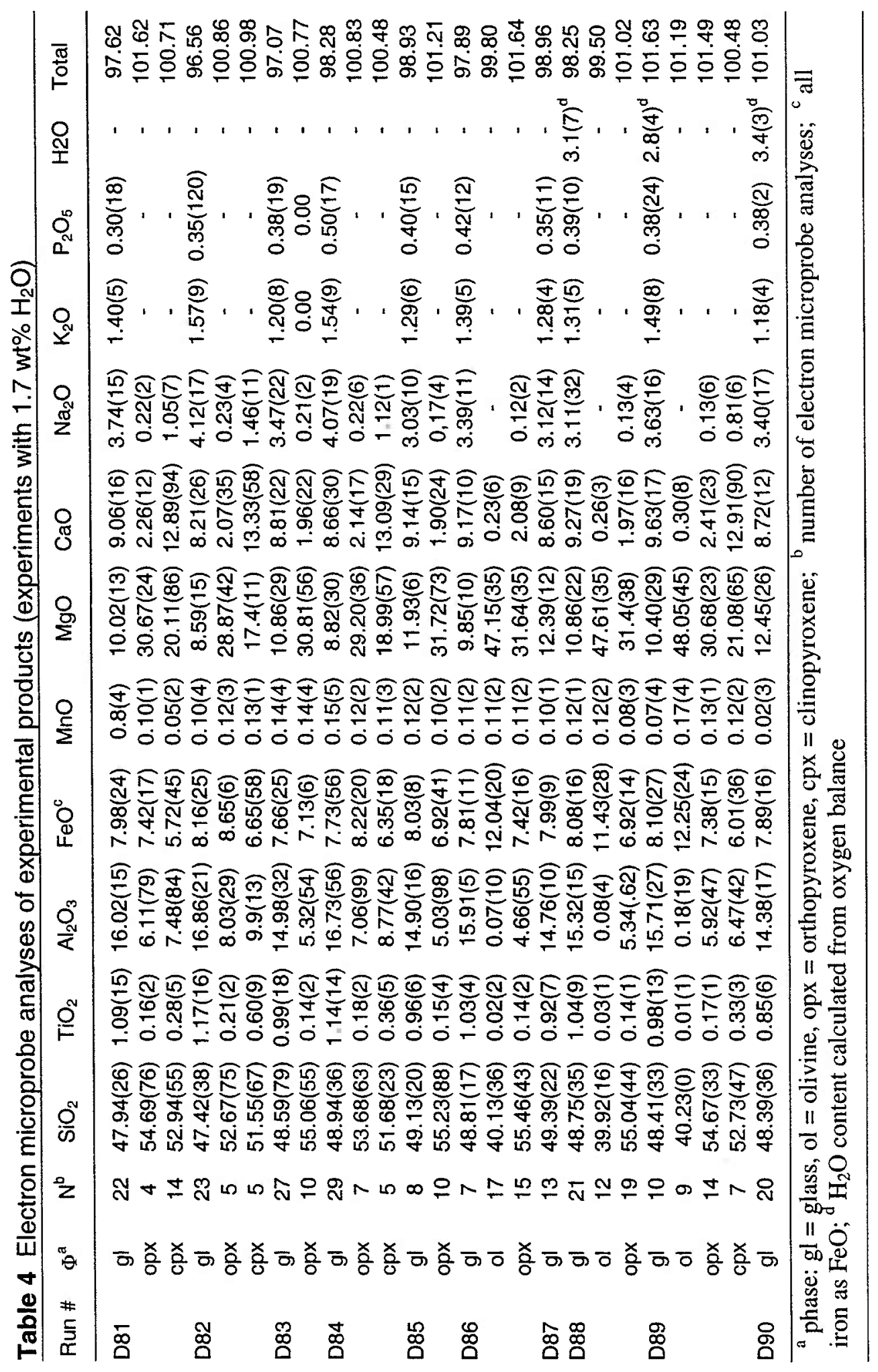



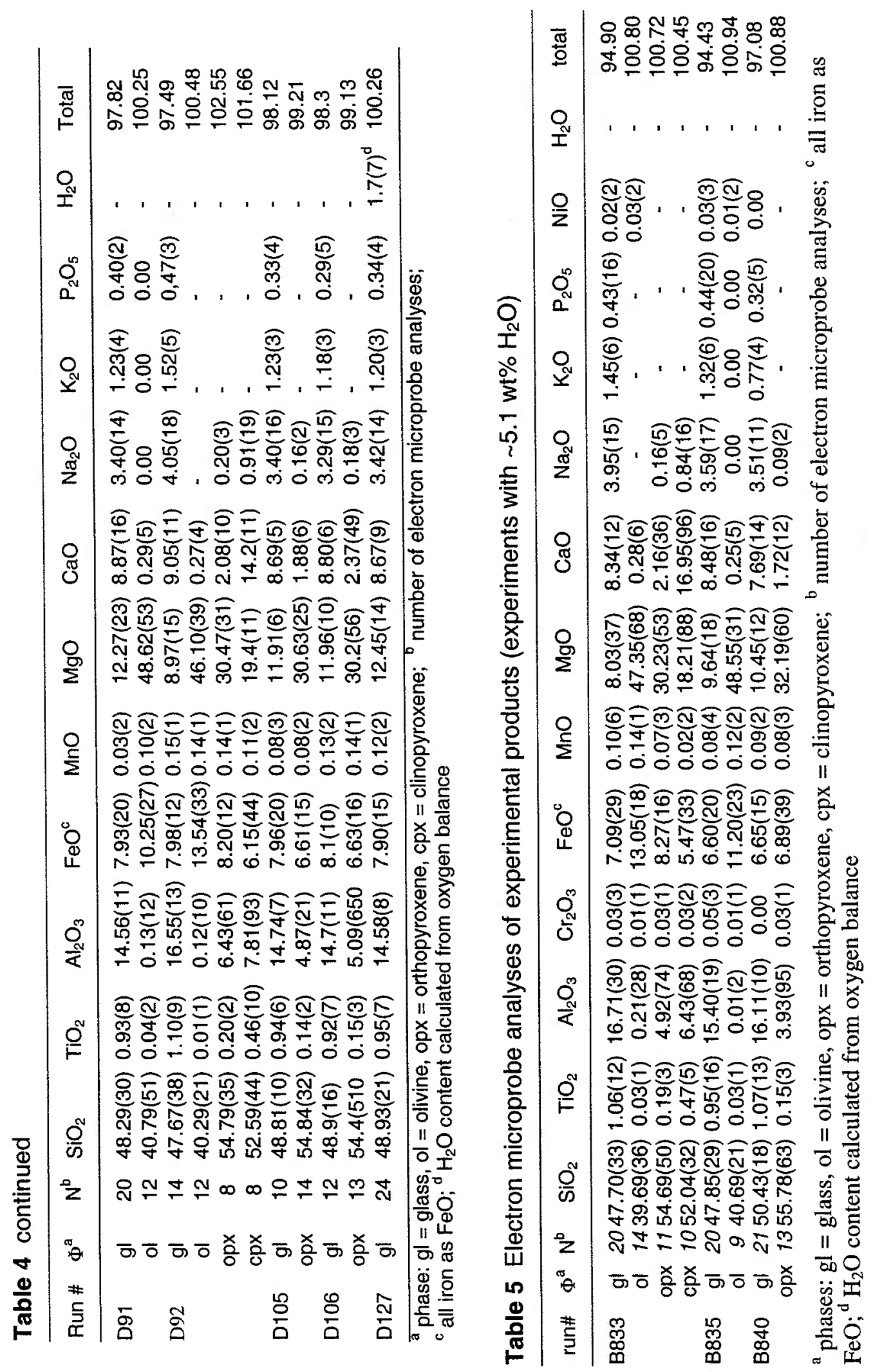


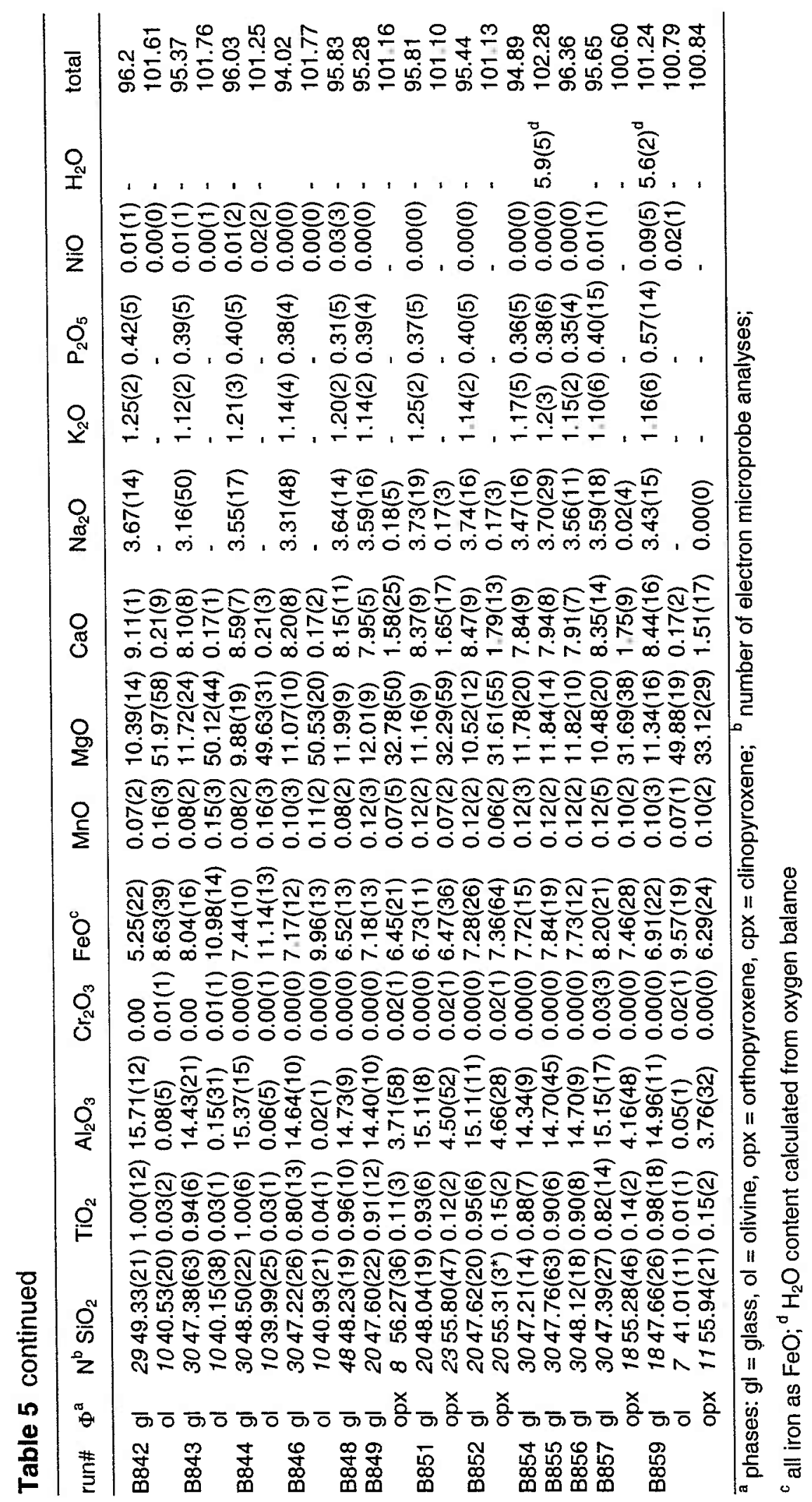


Table 6 Estimates of source and melt fraction

\begin{tabular}{llllll} 
& \multicolumn{2}{c}{ source components } & \multicolumn{2}{c}{ source estimates } \\
\cline { 2 - 6 } & $\mathrm{HZ}^{\mathrm{a}}$ & $\mathrm{LHZ}^{\mathrm{b}}$ & PLHZ & $\mathrm{S}-1.7^{\mathrm{d}}$ & $\mathrm{S}-5.1^{\mathrm{e}}$ \\
\hline $\mathrm{SiO}_{2}$ & 44.07 & 45.70 & 42.32 & 43.78 & 43.89 \\
$\mathrm{TiO}_{2}$ & 0.03 & 0.24 & 0.21 & 0.11 & 0.05 \\
$\mathrm{Al}_{2} \mathrm{O}_{3}$ & 0.69 & 4.21 & 3.31 & 1.85 & 0.95 \\
$\mathrm{FeO}^{*}$ & 8.05 & 8.61 & 14.59 & 9.95 & 8.70 \\
$\mathrm{MgO}$ & 46.42 & 37.08 & 37.27 & 42.74 & 45.50 \\
$\mathrm{CaO}$ & 0.69 & 3.74 & 1.99 & 1.42 & 0.82 \\
$\mathrm{Na}_{2} \mathrm{O}$ & 0.05 & 0.32 & 0.11 & 0.09 & 0.06 \\
$\mathrm{~K}_{2} \mathrm{O}$ & 0.01 & 0.11 & 0.18 & 0.07 & 0.03 \\
\hline $\mathrm{Mg \#}$ of source & & 0.88 & 0.90 \\
estimated melt fraction & & 2.9 & 1.6 \\
modal olivine in source & & 73.9 & 77.9 \\
modal opx in source & & 23.09 & 20.46 \\
$\left\|\mathrm{e}_{\mathrm{n}}\right\|^{\mathrm{g}}$ & & 0.62 & 0.43 \\
\hline
\end{tabular}

${ }^{a}$ Mexican xenolith SLP-114 from Luhr and Aranda-Gomez $1997{ }^{\mathrm{b}}$ Mexican xenolith DGO-165A from Luhr and Aranda-Gomez $1997^{c}$ Mexican xenolith SLP-400 from Luhr and Aranda-Gomez $1997^{\mathrm{d}}$ positive linear combination of HZ, LHZ \& PLHZ that is closest to a positive linear combination of the phases in multiply saturated experiment D88 ${ }^{\mathrm{e}}$ positive linear combination of $\mathrm{HZ}, \mathrm{LHZ} \&$ PLHZ that is closest to a positive linear combination of the phases in multiply saturated experiment $\mathrm{B} 859{ }^{\mathrm{f}} \mathrm{Mg \#}=$ molar $\mathrm{MgO} /(\mathrm{MgO}+\mathrm{FeO})^{\mathrm{g}}$ estimate by linear least squares massbalance of the phases in experiment D88 (B859) against a bulk composition of S-1.7 (S-5.1 ${ }^{\mathrm{h}}\left\|\mathrm{e}_{\mathrm{n}}\right\|$ length of the normalised error vector, see text for discussion. 


\section{Figure Captions}

Fig. $1 \mathrm{~K}_{2} \mathrm{O}$ vs. $\mathrm{SiO}_{2}$ diagram with boundaries from Peccerillo and Taylor (1976). Shown are all analysed samples from the Mascota volcanic field (Carmichael et al., 1996). We have chosen the most primitive sample M.102 a mildly potassic absarokite as our starting composition.

Fig. 2 The map of southwest Mexico, modified from Luhr (1997), shows important regional tectonic and geological features. The black star indicates the location of the Mascota volcanic field, in the Mascota graben. Faults are shown as dashed lines, large volcanic structure as black triangles. The extent of the Jalisco block on land is shown by the dark gray area. The Jalisco block is bounded by the Middle American trench in west and by the Colima rift zone (CR) and the Mazanillo submarine canyon (MC) in the east and south east and the Tepic-Zacoalo rift zone in the north west. At the eastern most tip of the Jalisco block the TZR and the CR meet the Chapala rift zone (ChR) to form a triple junction. Light gray lines show reconstructed Rivera plate motion (maximum change) relative to the North American plate (DeMets and Traylen, 2000). Thick white lines show the depth to the Wadati Benioff zone in kilometers. Note that the slab is nearly aseismic beneath the Jalisco block, and the last good depth estimates are beneath the Colima Rift (CR) (Pardo and Suarez, 1995).

Fig. 3 The hydrous assemblage used in experiments with mix MEX-5.1 is shown on the left. The $\mathrm{Au}_{80} \mathrm{Pd}_{20}$ capsule is surrounded by graphite and directly placed into a cavity in the basal $\mathrm{MgO}$ spacer. The left shows the dry assemblage used in experiments with mix MEX-1.7. Note the extra graphite necessary beneath the graphite capsule to prevent melt channels reaching the $\mathrm{MgO}$ spacers. Both assemblages are drawn to scale.

Fig. 4 Backscatter electron image, from experiment D92, illustration the high mobility of the melt in the graphite capsule.

Fig. $5 \mathrm{CaO}$ and $\mathrm{Al}_{2} \mathrm{O}_{3}$ contents in clinopyroxenes (cpx's) from different experimental studies. The grey shaded area shows our cpx's from runs with $1.7 \mathrm{wt} \% \mathrm{H}_{2} \mathrm{O}$. The experiment containing cpx just $30^{\circ} \mathrm{C}$ below the liquidus at the pressure of multiple saturation is labelled "B88". The only cpx produced using bulk composition MEX-5 is labelled "B833". (Elkins Tanton and Grove) are cpx's from a liquidus study of a olivine-leucitite that is inferred to have segregated from a phlogopite-clinopyroxenite source. 
Kinzler and Grove (1992) and Gaetani and Grove (1998) (dry) are cpx's from dry experiments that are multiply saturated with mantle peridotite. Gaetani \& Grove (1998) (hydrous) are cpx's from hydrous experiments multiply saturated with four mantle phases. Pickering-Witter and Johnston (2000) and Schwab and Johnston (2001) are residual cpx's from dry, low melt-fraction peridotite melting experiments at $1 \mathrm{Gpa}$. Robinson et al. (1998) are cpx's from dry basalt-peridotite sandwich experiments multiply saturated with mantle peridotite at $1.5 \mathrm{GPa}$. Lloyd et al. (1985) are residual cpx's from phlogopite-clinopyroxenite melting experiments at 2 and $3 \mathrm{GPa}$.

Fig 6a Pressure-temperature diagram showing the results of melting experiments with $1.7 \mathrm{wt} \% \mathrm{H}_{2} \mathrm{O}$. Each square represents one experiment and indicates the phases present (ol $=$ olivine, $\mathrm{opx}=$ orthopyroxene, $\mathrm{cpx}=$ clinopyroxene). All lines are interpretations. The uncertainty in temperature is believed to be $\pm 10^{\circ} \mathrm{C}$.

Fig 6b Pressure-temperature diagram showing the results of melting experiments with 5.1 wt\%. Each square represents one experiment and indicates phases present, with same abbreviations as in Figure $6 a$.

Fig. 7 Two pseudo-ternary projections using the projections of the less hydrous 1.6 GPa data. In the foreground is the olivine-diopside-plagioclase projection (ol-di-plag) (Grove, 1993). Note that the orthopyroxenes have a negative diopside component and plot below the base of the triangle in both projections. Olivines are not shown in ol-di-plag projection. In the background is the olivine-diopsidequartz projection, with our interpretation of the phase/reaction boundaries. Boundaries where not added to the ol-di-plag projection because the liquid compositions are essentially constant. The circle with diagonal cross, shows the composition of a dry melt saturated with all four mantle phases at $1.6 \mathrm{GPa}$, the composition is from experiment H179, Kinzler and Grove (1992).

Fig. 8 Show the change in pressure of multiple saturation due to $15-25 \%$ Fe-loss. All experiments shown, used composition MEX-5.1. Grey symbols are experiments with less than $10 \%$ Fe-loss, from Figure 5b. Black symbols are experiments with $15-25 \%$ Fe-loss, that are not reported in Table $3 \& 5$. Black arrow shows the change in the pressure of olivine and orthopyroxene stability, due to Fe-loss

Fig. 9a \& $\mathbf{b}$ The variation of melt-fraction $F$ with changes in source compositions is shown (solid lines). The linear compositional space is spanned by a harzburgite (HZ) a fertile lherzolite (LHZ) and a 
metasomatised phlogopite-lherzolite (PLHZ), see Table 6 for compositions. The left graph shows the results for the multiply saturated assemblage from experiment D88 with $\sim 1.7 \% \mathrm{H}_{2} \mathrm{O}$ (Table 4 ). The graph on the right shows the results for the multiply saturated assemblage B859 with $\sim 5.1 \mathrm{wt} \%$ $\mathrm{H}_{2} \mathrm{O}$ (Table 5). The melt-fraction (solid lines) has been calculated using least squares mass balance, and the relative error in \% is shown (dashed lines). Black stars indicate the optimal source compositions, which are also given in Table 6 (S-1.7 \& S-5.1). The black triangles give the optimal source using two different measures of error. The exact composition of the source depends on the error criterion chosen, but in all three cases, a depleted lherzolite or harzburgite source gives very small errors and an apparent melt fraction below $5 \%$.

Fig. 10 Compares estimates of pressure and temperature in the Mexican mantle. Crosses are T \& P estimates from two-pyroxene geothermometry and olivine clinopyroxene Ca-exchange geobarometry on Mexican spinel-peridotite xenoliths (Luhr and Aranda Gomez, 1997). Note that these xenoliths are from Mesas Central, north of the Mexican volcanic belt. Open squares, circles and upside down triangles are $\mathrm{T} \& \mathrm{P}$ estimates for minettes from the Jalisco block, based on partitioning of $\mathrm{BaO}$ and $\mathrm{TiO}_{2}$ between phlogopite and liquid (Righter and Carmichael, 1996). Triangles are the T \& P conditions of the multiple saturation points of our experiments with $\sim 1.7 \mathrm{wt} \% \mathrm{H}_{2} \mathrm{O}$ and $\sim 5.1 \mathrm{wt} \% \mathrm{H}_{2} \mathrm{O}$. Grey triangle is and extrapolation of the pressure and temperature of multiple saturation to $6 \mathrm{wt} \% \mathrm{H}_{2} \mathrm{O}$.

Fig. 11 The compositional space is spanned by harzburgite (HZ) and two different vein compositions, simulating a veined harzburgitic mantle. The melt-fraction (solid lines) has been calculated using least squares mass-balance, and the sum of the squared residuals is shown as a measure of error in the massbalance (dashed lines) Phlogopite-clinopyroxenite is the composition studied by Lloyd et al. (1985). Gimmerite consists more than $90 \%$ phlogopite and minor ilmenite and calcite, the composition is sample AJE 281 from Gregoire et al. (2002). The black star indicates the best estimate of the source composition.

Fig. 12 Spidergram showing calculated abundance of the incompatible elements $\mathrm{Ba}, \mathrm{Rb}, \mathrm{Sr}, \mathrm{Nb}$ and $\mathrm{Y}$ necessary in the fluid, to produce and average Mascota absarokite by partially melting $(F=5 \%)$ four different source materials. On the top the logarithm of the bulk distribution coefficient $D$ for the different elements is shown. $\mathrm{D}$ has been calculated by assuming a 0.5 olivine +0.5 opx residue and using data compiled in Grove et al. (2002). DM is a depleted mantle composition from Grove et al. 
(2002). The three PP compositions are phlogopite peridotites from (Erlank et al., 1987), see Table IV p. 278. PP min is the least enriched, PP ave is the average composition, and PP max is the most enriched of 17 samples.

Fig. 13 Schematic illustration of our model for the origin of the Mexican absarokites. Depleted mantle is drawn into the mantle wedge along the grey flow line. It is hydrated as it descends above the dehydrating slab (black dots). As temperature and pressure increase the hydrous phases break down and a Na and $\mathrm{K}$ rich fluid migrates upwards (black wavy lines). They move upward until the hydrous solidus is reached (dashed black line) and a hydrous alkaline melt forms (original source OS). The melt ascends through the mantle wedge (grey column), and finally equilibrates, at the multiple saturation point with a harzburgite residue at $\sim 50 \mathrm{~km}$ depth (major element source MS). It is then extracted without significant modification and erupted on the surface. 
Figures

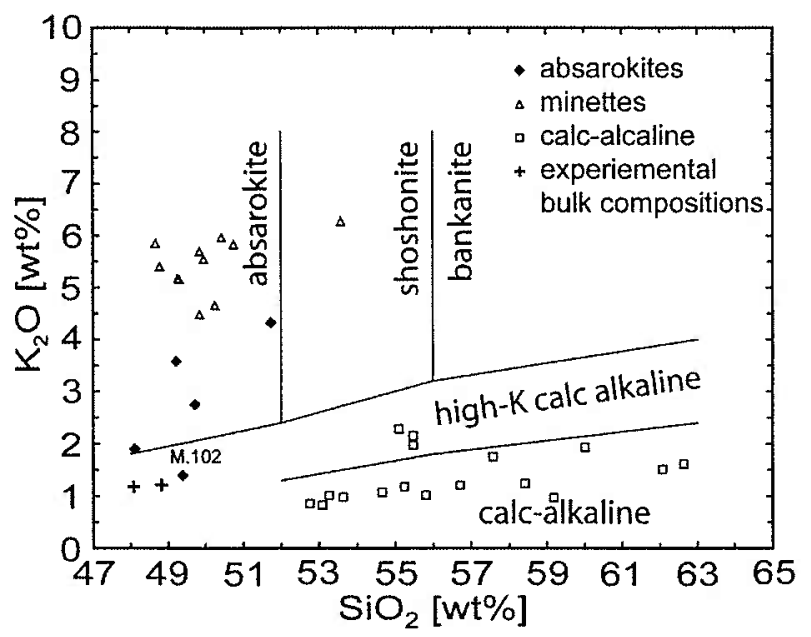

Fig. 1

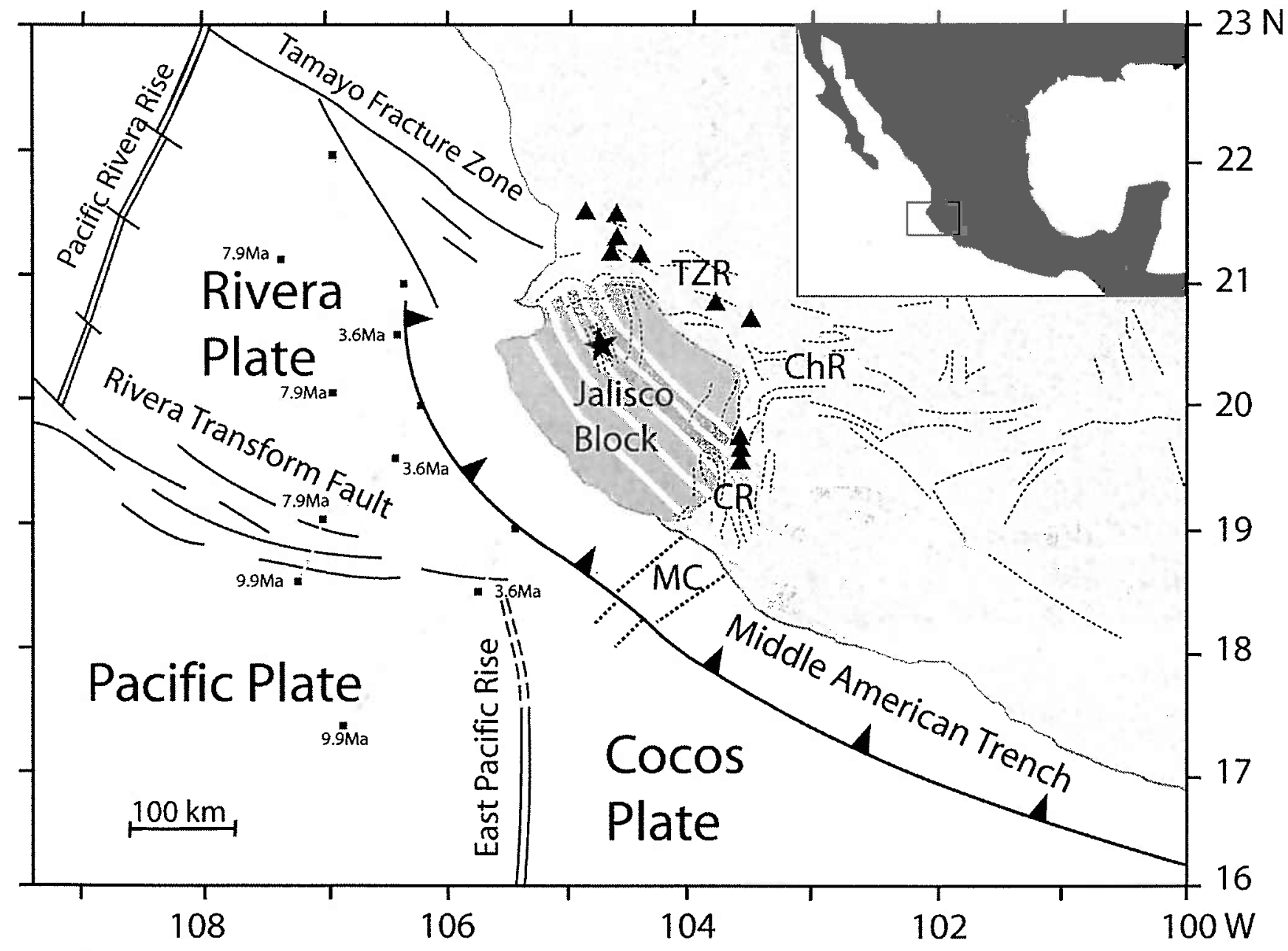

Fig. 2 


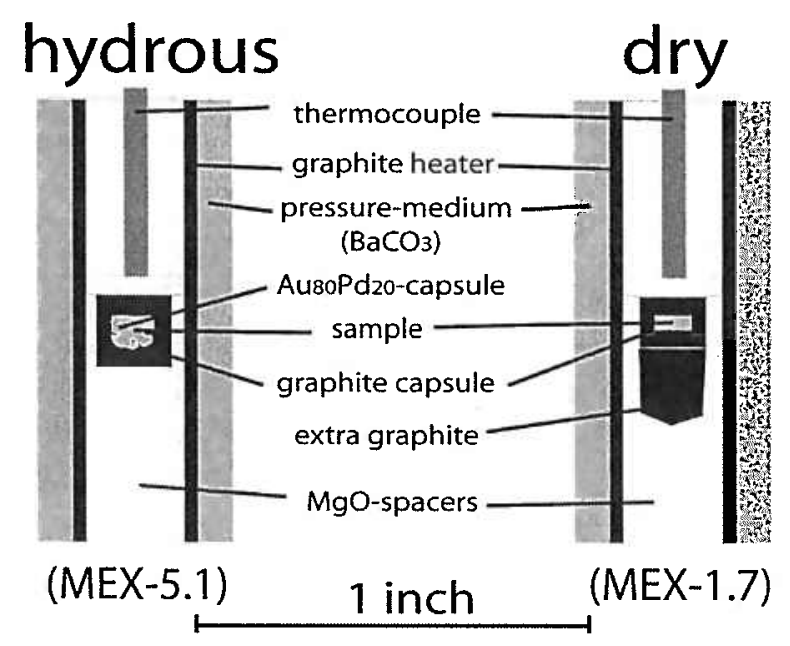

Fig. 3

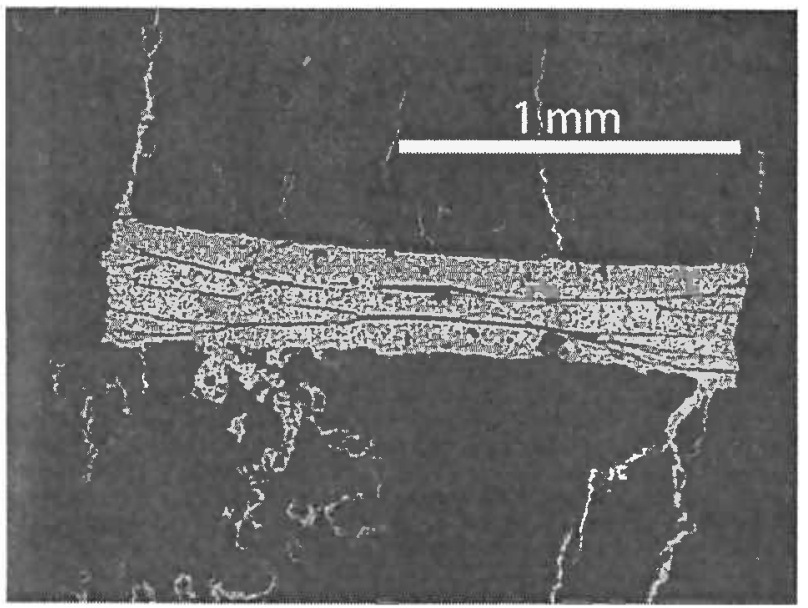

Fig. 4

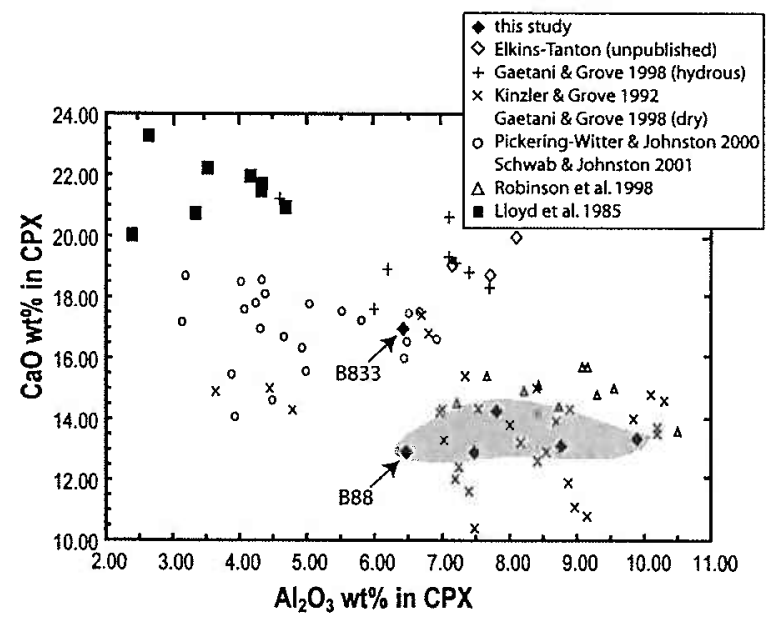

Fig. 5 

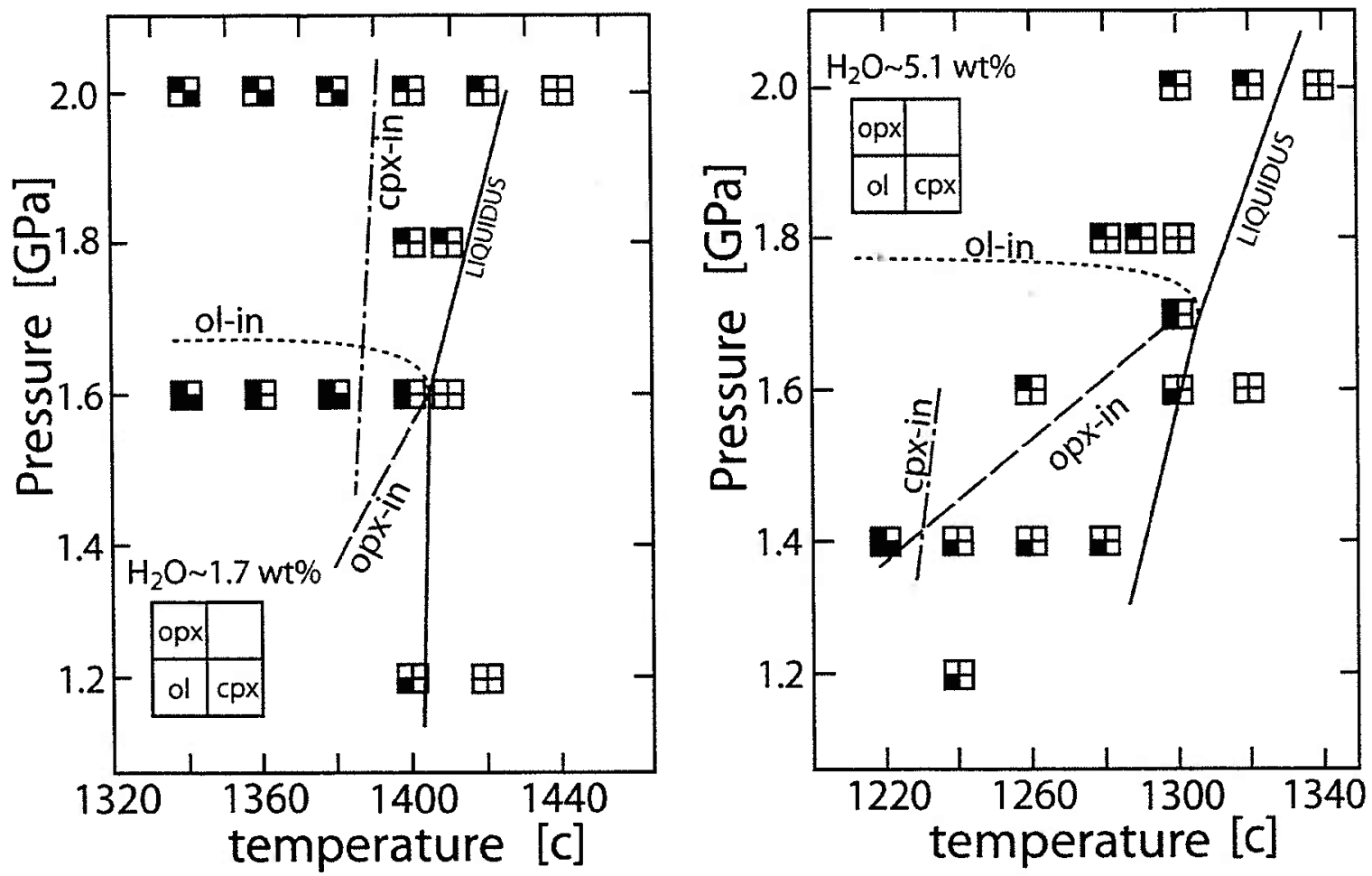

Fig. 6a\&b

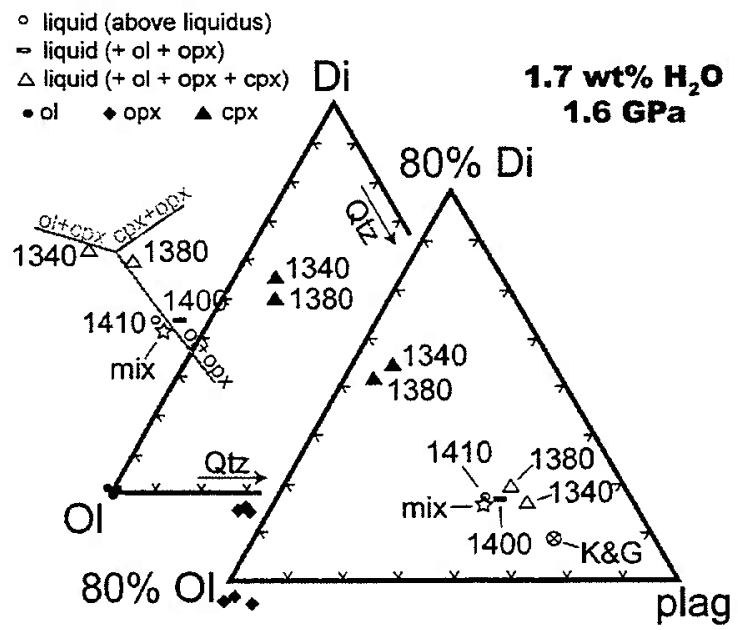

Fig. 7 


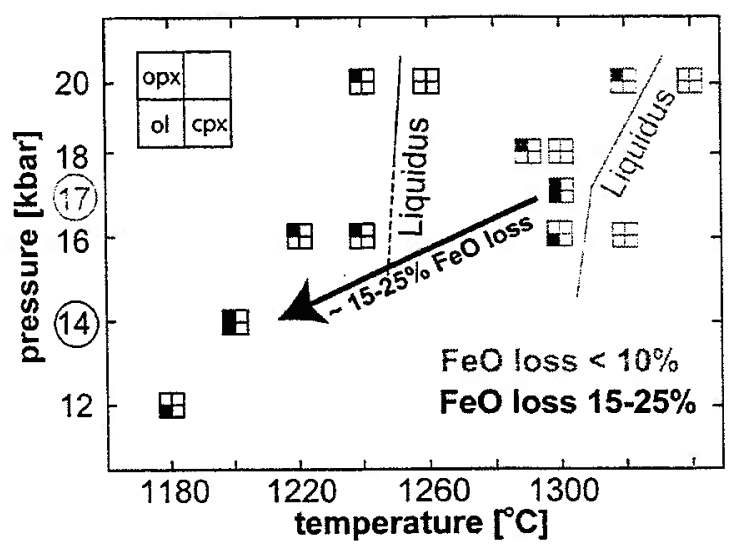

Fig. 8
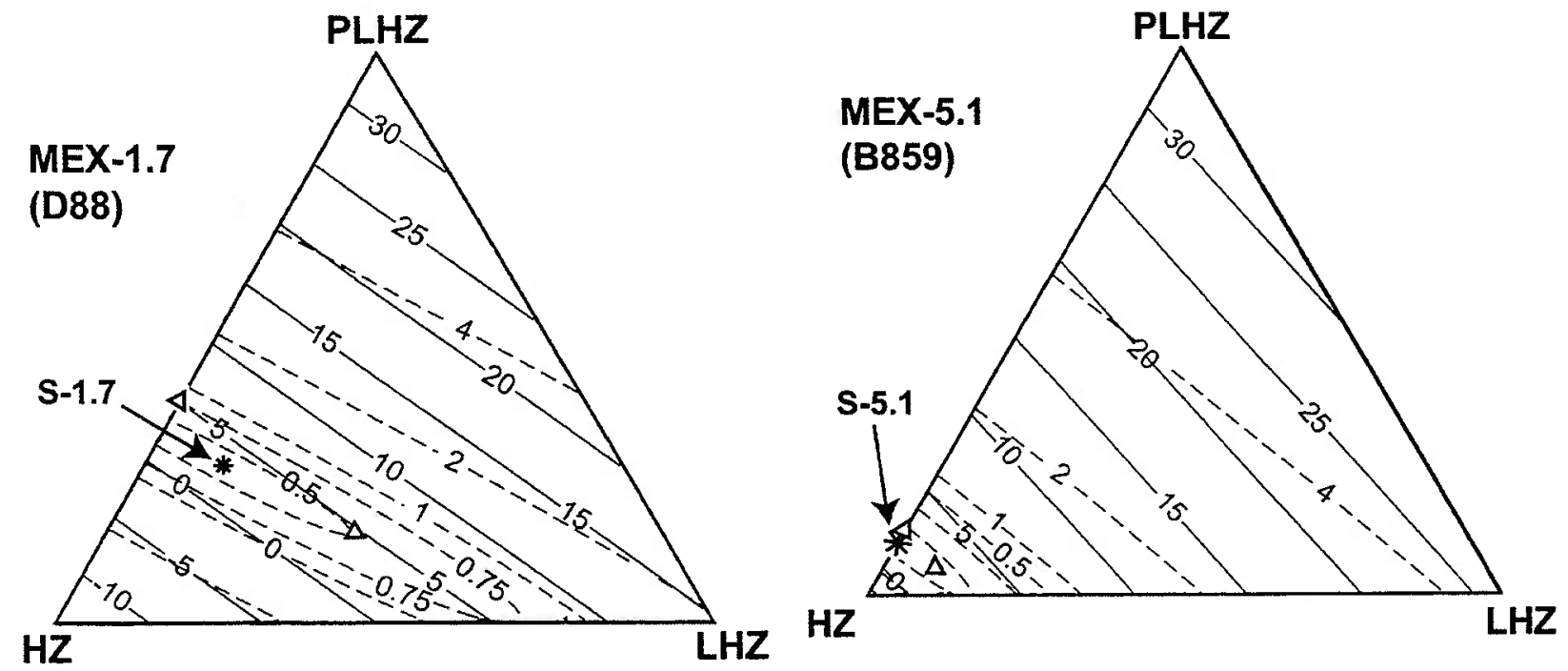

Fig. 9a\&b 


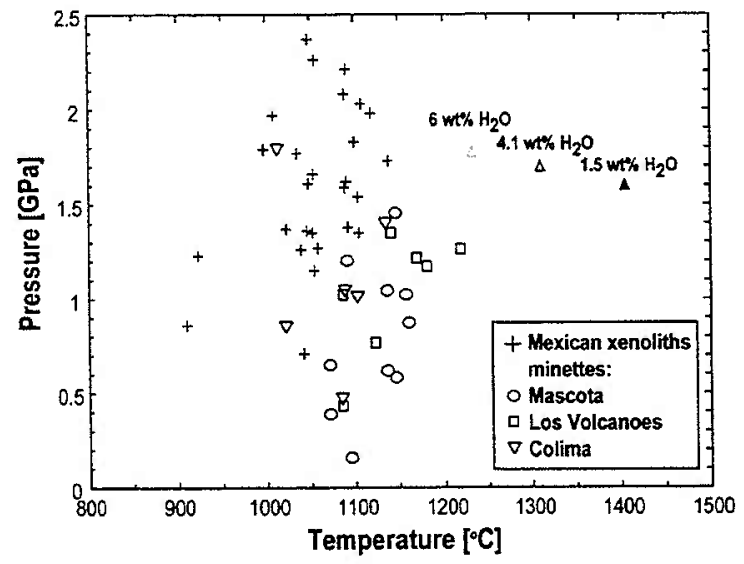

Fig. 10

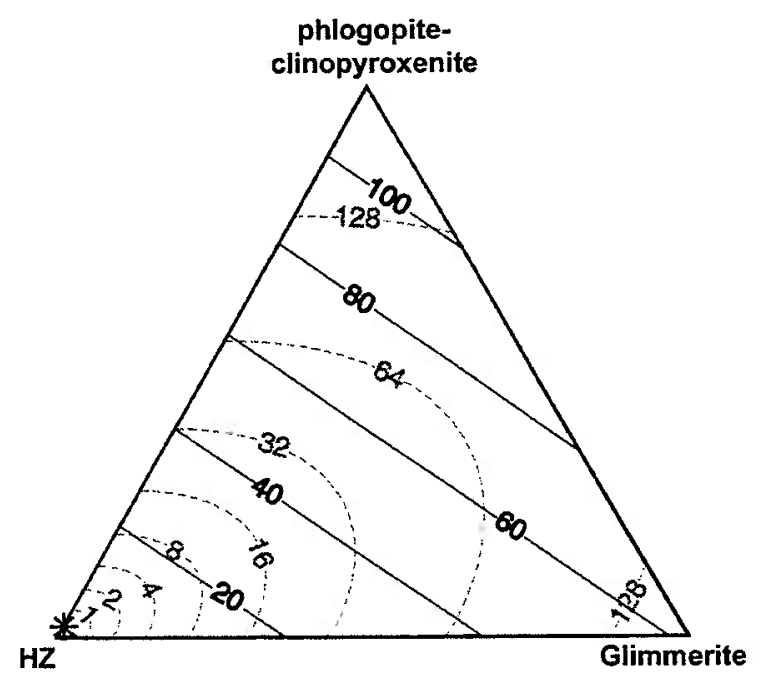

Fig. 11 


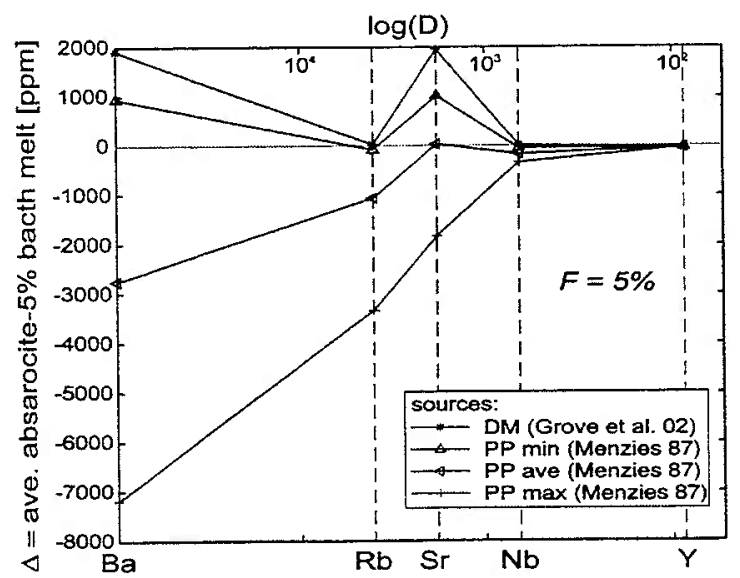

Fig. 12

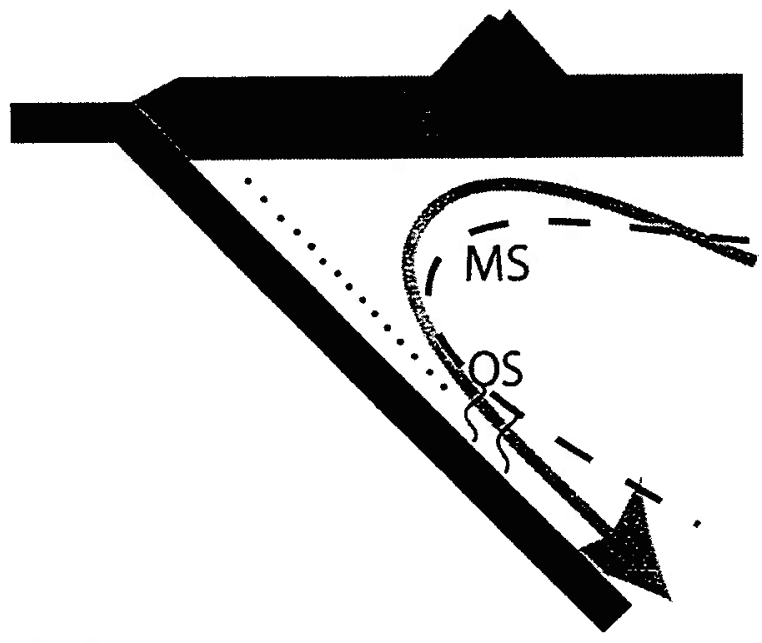

Fig. 13 